\title{
A Critical Review on Advancement and Challenges of Biochar Application in Paddy Fields: Environmental and Life Cycle Cost Analysis
}

\author{
Ali Mohammadi ${ }^{1, *(\mathbb{D}}$, Benyamin Khoshnevisan ${ }^{2}{ }^{\mathbb{C}}$, G. Venkatesh ${ }^{1}$ and Samieh Eskandari ${ }^{1}(\mathbb{C}$ \\ 1 Department of Engineering and Chemical Sciences, Karlstad University, 65188 Karlstad, Sweden; \\ venkatesh.govindarajan@kau.se (G.V.); samie.eskandari@gmail.com (S.E.) \\ 2 Key Laboratory of Non-Point Source Pollution of Ministry of Agricultural and Rural Affairs, \\ Institute of Agricultural Resources and Regional Planning, Chinese Academy of Agricultural Sciences, \\ Beijing 100081, China; Benkho@caas.cn \\ * Correspondence: ali.mohammadi@kau.se; Tel.: +46-54-700-2480
}

Received: 9 August 2020; Accepted: 9 October 2020; Published: 12 October 2020

\begin{abstract}
Paddy fields emit considerable amounts of methane $\left(\mathrm{CH}_{4}\right)$, which is a potent greenhouse gas (GHG) and, thereby, causes significant environmental impacts, even as they generate wealth and jobs directly in the agricultural sector, and indirectly in the food-processing sector. Application of biochar in rice production systems will not just help to truncate their carbon footprints, but also add to the bottom-line. In this work, the authors have reviewed the literature on climate change, human health, and economic impacts of using organic residues to make biochar for the addition to croplands especially to rice paddy fields. Biochar-bioenergy systems range in scale from small household cook-stoves to large industrial pyrolysis plants. Biochar can be purveyed in different forms - raw, mineral-enriched, or blended with compost. The review of published environmental life cycle assessment (E-LCA) studies showed biochar has the potential to mitigate the carbon footprint of farming systems through a range of mechanisms. The most important factors are the stabilization of the carbon in the biochar and the generation of recoverable energy from pyrolysis gases produced as co-products with biochar as well as decreased fertiliser requirement and enhanced crop productivity. The quantitative review of E-LCA studies concluded that the carbon footprint of rice produced in biochar-treated soil was estimated to range from -1.43 to $2.79 \mathrm{~kg} \mathrm{CO}_{2}$-eq per $\mathrm{kg}$ rice grain, implying a significant reduction relative to rice produced without a biochar soil amendment. The suppression of soil-methane emission due to the biochar addition is the dominant process with a negative contribution of $40-70 \%$ in the climate change mitigation of rice production. The review of the life cycle cost studies on biochar use as an additive in farmlands demonstrated that biochar application can be an economically-feasible approach in some conditions. Strategies like the subsidization of the initial biochar capital cost and assignment of a non-trivial price for carbon abatement in future pricing mechanisms will enhance the economic benefits for the rice farmers.
\end{abstract}

Keywords: rice cropping systems; biochar; pyrolysis gas; E-LCA; carbon abatement; human health; economic analysis

\section{Introduction}

Recent studies have provided important information on climate change mitigation. The current greenhouse gas (GHG) emissions trend suggests that the average global temperature will rise by over $4{ }^{\circ} \mathrm{C}$ by 2100 [1,2]. Since global warming may adversely affect biodiversity, ecosystems, and human survival [3], many scientists have shown a renewed interest in new approaches to geo-engineering and reforestation through which excess carbon dioxide $\left(\mathrm{CO}_{2}\right)$ from the atmosphere 
can be removed [4,5]. Existing research recognizes the critical role played by biochar production (a solid product of thermal decomposition of biomass) and its application into soils in mitigating atmospheric $\mathrm{CO}_{2}$ concentrations [6].

Rice paddy fields have been identified as a major source of atmospheric GHG emissions, mainly in the form of methane $\left(\mathrm{CH}_{4}\right)$. Climate change impact and its adaptation strategies can positively or negatively affect rice production [7] and net income of rice farmers [8,9]. Biochar use in rice systems has been advocated as a potential strategy to reduce GHG emissions from soils [10-12], enhance soil carbon (C) stocks and nitrogen $(\mathrm{N})$ retention [13,14], and improve soil function and crop productivity [12,15]. In agricultural systems, crop residues could be a sustainable source of biomass for biochar production and bioenergy generation. Unused agricultural residues are currently decomposed in the soil or burned in the field, returning most of the $\mathrm{C}$ to the atmosphere. Converting all sustainably-harvested biomass into biochar could reduce the atmospheric loading of $\mathrm{CO}_{2}$ by $1.8 \mathrm{Gt} \mathrm{C} / \mathrm{yr}$ [16]. Using residues for biochar production may also abate the emissions of atmospheric pollutants caused by open burning of biomass. Burning crop residues in the field is particularly dangerous to human health since most of the particulate matter with a diameter of less than $10 \mu \mathrm{m}\left(\mathrm{PM}_{10}\right)$ is easily able to penetrate deep into the lungs, causing respiratory disorders and heart problems [17].

Biochar stability in soil alone is not sufficient to quantify the impact of biochar amendments on net GHG emissions [18]. It is also necessary to consider emissions associated with growing, harvesting, and transporting feedstock as well as with biochar production and its land application. Environmental life cycle assessment (E-LCA) integrates these varied sources of emissions associated with biochar addition to soil to quantify the system-level impacts on terrestrial carbon stocks and atmospheric GHG concentrations. E-LCA is an analytical tool that can be applied to calculate the life-cycle environmental impacts of products/product-systems. It adheres to global ISO standards and is comprised of four steps-defining the goal and scope of the analysis, inventory analysis (of the inputs into and outputs from the life-cycle), environmental impact assessment, and interpretation of the results and generation of advice for improvement [19]. The use of E-LCA enables researchers to evaluate biochar production throughout its life cycle, introduce the hotspots, and find solutions to mitigate the potential impacts [20]. Accordingly, numerous studies have employed this method to scrutinize the potential impacts of biochar production and application as an energy source or as a soil amendment [21]. Among other aspects of biochar production, a number of studies have employed E-LCA to evaluate the environmental impacts of biochar application in paddy fields. However, due to the varied characteristics of biochar, its versatile impacts on the rice fields as well as different methodological choices made the functional unit and the definition of the system boundaries such as the results achieved from these studies, which are considerably different.

Optimal use of new technologies is possible only when they are quickly adopted and widely diffused. While the increase in yield may be a plus for new agricultural technology, the high costs may be a deterrent [22,23]. Therefore, prior to widespread promotion of biochar systems, it is important to investigate the economic implications of biochar systems vis-à-vis conventional systems.

The aim of this review is to provide an overview of biochar production systems in terms of climate change, health, and economic impacts, and discuss the key factors affecting the final results, particularly with regard to rice-based farming systems.

\section{Environmental Life Cycle Assessment (E-LCA)}

E-LCA, as referred to earlier, can also be labelled as a 'cradle-to-grave' (or cradle-to-cradle more accurately, when there is recycling and reuse involved at the end of the linear life-cycle, thus circularizing it) environmental impact analysis, and is a sustainability tool that can be applied to asses any product, process, or activity in the anthroposphere. The entire life cycle here would encompass everything from raw material acquisition, manufacturing/production, use, and final disposal (which may take any form). The four standard steps in an E-LCA have been briefly described below. 


\subsection{Goal and Scope Definition}

Goal and scope definition is the first phase of LCA, and is equivalent to defining the objective and the boundary of the study to be performed. The objective of the study is described in terms of the environmental impacts associated with a functional unit. The functional unit (FU) is the reference unit for which the inventory data are normalised [19].

\subsection{Inventory Analysis}

Inventory analysis involves the collection of data concerning resource use, energy consumption, emissions to the environment, and products resulting from each activity in the product system. The life cycle inventory (LCI) table presents information about all inputs and outputs in the form of elementary flows to and from the environment from all the unit processes involved in the study. LCI database can assist researchers in the selection of energy-efficient and environmentally friendly materials, products, and processes for their study systems based on the environmental impact of an object over its entire lifetime.

\subsection{Impact Assessment}

Life cycle impact assessment (LCIA) aims at quantifying the potential environmental impact of the elementary flows identified in the LCI phase. Therefore, this stage considers the contribution to impact categories such as climate change, particulate matter, and acidification. In the first step, impact potentials are computed according to the LCI results. Normalisation and weighting are two optional steps. Normalisation provides a basis for aggregating similar environmental impacts caused by different substances using characterisation factors. Weighting enables one to aggregate different impact categories to get a single index by assigning priorities to them. The impact assessment involves the application of characterization factors, based on mid-point or end-point indicators for each impact category. For instance, the characterisation factors of biogenic methane $\left(\mathrm{CH}_{4}\right)$, and nitrous oxide $\left(\mathrm{N}_{2} \mathrm{O}\right)$ are 28 and 265, respectively, for the calculation of climate change over a 100-year time horizon, according to the IPCC Fifth Assessment Report [24].

\subsection{Interpretation}

The interpretation of the results from the previous stages of the study is the final stage in the life cycle assessment (LCA). All conclusions and recommendations related to the objectives of the study are formulated during this stage.

\section{Life Cycle Cost Analysis (LCCA)}

LCCA is much older than E-LCA, and had its roots in the USA much like E-LCA. It enables one to understand if decisions made, guarantee economic sustainability. LCCA enables one to chalk out different scenarios and have a long list of plans. When one considers a long business life-cycle, depending on the kind of business and its degree of reliance on material and energy resources, resource economics plays a key role in LCCA as a source of data. Simply put, LCCA advocates a long-term perspective [25]

The cheapest option on the shelf may very well have a shorter lifetime necessitating a fresh investment and new purchases again very soon. It may also mean that you end up spending more on maintaining whatever you purchased, as it may tend to breakdown very often. Here, we can define an acronym, which one would come across often in LCCA - the total cost of ownership of an asset. When there is 'ownership,' there is the necessity (and the responsibility) to spend on operation and maintenance. The total cost of ownership is nothing but the sum total of the initial cost and the operation-maintenance expenses incurred throughout the life cycle. LCCA has struck deep roots in both the developed and developing world countries in the previous century and has been applied in a different range of subjects [26-28]. Entrenching LCCA in decision-making will go a long way 
in promoting the conservation of natural resources, when inflation resulting from the impending scarcity of the non-renewable resources is factored into an LCCA, revealing a rise in operation expenses later in the life-cycle. This may mean that decisions will tend to be made in favour of resource-lighter alternatives. Being fully aware that scarcity of some of the resources you need, correlating directly to cost, is a 'good weapon' to have. If a decision is likely to save a lot of money (this would vary depending on the range of alternatives, the type of project/asset, and the sector in focus), then all the time and effort invested in performing an LCCA is fully worth it. The following factors make the adoption of LCCA unquestionable [25]:

- High energy-intensiveness of the projects during their respective lifetimes, in a clime in which it is a known fact that energy prices will increase,

- High project lifetimes, and, thereby, near certainty that the operation and maintenance expenses that must be managed, cannot be ignored,

- High initial capital cost, which needs to be justified by an optimisation of operation and maintenance expenses.

\section{Biochar}

\subsection{Biochar in Farming Systems}

Application of biochar to cropland has been recommended as a climate-change mitigation approach, which also improves soil properties. Biochar is produced through pyrolysis of uncontaminated and sustainable biomass source, e.g., wood, crop residues, livestock manure, or other organic wastes at a low temperature $\left(300-600^{\circ} \mathrm{C}\right.$ ) in oxygen-limited anoxic conditions. The resultant, which can be applied to the soil, has a high non-biodegradable carbon content that can remain in the soil for hundreds to thousands of years [29]. The stability of carbon in biochar varies depending on the feedstock and pyrolysis temperature. Singh et al. [30] found that the stable carbon content of biochar from slow pyrolysis ranged from $45 \%$ (poultry litter pyrolysed at $400{ }^{\circ} \mathrm{C}$ ) to $92 \%$ (wood feedstock pyrolysed at $550^{\circ} \mathrm{C}$ ). The much greater long-term stability of carbon in biochar compared with conventional methods for disposal of biomass [31] is this approach's USP when it comes to carbon sequestration methods.

The reviews of studies over biochar additions to soil indicate that biochar can increase crop yield [32], suppress GHG emissions from soil [33], reduce fertiliser requirements [34,35], and increase soil organic carbon stocks [36]. However, the agronomic and soil impacts of biochar use in farming systems vary widely, and differences are due to feedstock and pyrolysis conditions, biochar application rate, and crop and soil to which biochar is applied [37], resulting in large uncertainties in the effect of biochar on crop yields and soil GHG emissions.

For instance, the review of studies on the effects of biochar amendment on GHG emissions from paddy soils demonstrated that results vary broadly, fluctuating from a large increase to a large decrease in soil $\mathrm{CH}_{4}$ emissions. Many studies have reported that biochar application significantly decreases $\mathrm{CH}_{4}$ emissions [11,38-40], which has been attributed mainly to an increase in soil pH [40] and increased methanotrophic activity because of improved soil aeration $[39,41]$. In contrast, enhanced $\mathrm{CH}_{4}$ production or no significant effect of biochar addition have also been reported [13,42], and the increased $\mathrm{CH}_{4}$ emissions with biochar addition has been attributed to the labile carbon from biochar as a predominant source of substrate for methanogenesis [43].

Similarly, studies have reported inconsistent findings on the effects of biochar amendment on $\mathrm{N}_{2} \mathrm{O}$ (nitrous oxide) emissions. Zhang et al. [44] found that the application of wheat straw biochar reduced soil bulk density and improved soil aeration, resulting in decreased $\mathrm{N}_{2} \mathrm{O}$ emissions. Yanai et al. [45] suggested that the increase in soil $\mathrm{pH}$ resulting from biochar addition made from municipal biowaste enhanced the $\mathrm{N}_{2} \mathrm{O}$-reducing activity of denitrifying communities. A meta-analysis carried out on biochar studies [33] calculated that biochar application reduced $\mathrm{N}_{2} \mathrm{O}$ emissions from soil by an average of $54 \%$. However, an increase in $\mathrm{N}_{2} \mathrm{O}$ emissions after biochar use have also been reported. 
The increasing soil $\mathrm{N}_{2} \mathrm{O}$ emissions were mostly attributed to the high levels of nitrogen input from the biochar addition $[40,46]$.

Biochar is also able to increase the growth and yield of rice $[15,38]$ and other dryland crops $[47,48]$ by improving the physical and biochemical properties of the soil, and nutrient availability $[49,50]$. Furthermore, the application of biochar in rice fields showed positive improvements on water use efficiency by $15.1-42.5 \%$, which was followed by an increased rice yield by $9.35-36.3 \%$ [51].

Ammonia volatilization is another source of atmospheric pollution from rice fields. The incorporation of biochar into paddy fields have reportedly decreased ammonia volatilization by absorbing ammonia and ammonium nitrogen. Ammonia volatilization could decrease up to $39 \%$ under soil treatments with $10 \mathrm{tha}^{-1}$ biochar [52]. Biochar properties, application rate, irrigation regime, etc. affect the rate of ammonia volatilization from rice fields (Table 1). There are also reports on a higher volatilization rate from paddy fields amended with straw biochar [53].

Table 1. A summary of recent publications (2016-2020) concerning the effects of biochar application on environmental pollutions from paddy rice fields (BC: biochar, CEC: cation exchange capacity, TC: total carbon, TN: total nitrogen).

\begin{tabular}{|c|c|c|c|c|c|}
\hline Reference & BC Substrate & BC Properties & Parameter & Application Rate & Effect \\
\hline [54] & Rice straw & $\begin{array}{c}\mathrm{pH}=10.58 \\
\mathrm{CEC}= \\
50.6 \mathrm{cmol} / \mathrm{kg} \\
\mathrm{TN}=1.08 \% \\
\mathrm{TC}=47.21 \%\end{array}$ & $\begin{array}{c}\mathrm{NH}_{3} \\
\text { volatilization }\end{array}$ & $\begin{array}{l}2.8 \text { and } 22.5 \text { tonne } \\
(\mathrm{t}) / \mathrm{ha}\end{array}$ & $\begin{array}{l}\text { - } 20 \% \text { reduction in } \mathrm{NH}_{3} \text { volatilization } \\
\text { - Highest } \mathrm{NH}_{3}-\mathrm{N} / \mathrm{TN} \text { under higher } \mathrm{BC} \text { rate } \\
\text { - Highest plant } \mathrm{N} \text { aboveground under a low } \\
\mathrm{BC} \text { rate }\end{array}$ \\
\hline [52] & Canola straws & $\begin{array}{c}\mathrm{pH}=8.9 \\
\mathrm{TC}=65 \% \\
\mathrm{TN}=0.23 \%\end{array}$ & $\begin{array}{c}\quad \mathrm{NH}_{3} \\
\text { volatilization } \\
\mathrm{N}_{2} \mathrm{O} \text { emission }\end{array}$ & $10 \mathrm{t} / \mathrm{ha}$ & $\begin{array}{l}\text { - } \mathrm{BC} \text { mixed with calcium superphosphate } \\
\text { reduced } \mathrm{NH}_{3} \text { losses by } 39 \% \\
-\mathrm{N}_{2} \mathrm{O} \text { reduced by } 19.5 \% \\
\text { - } \mathrm{BC} \text { alone decreased } \mathrm{N}_{2} \mathrm{O} \text { by } 24 \%\end{array}$ \\
\hline [12] & Rice straw & $\begin{array}{c}\mathrm{pH}=10.1 \\
\mathrm{TC}=42.6 \% \\
\mathrm{TN}=0.75 \%\end{array}$ & $\begin{array}{l}\mathrm{CH}_{4} \text { emission } \\
\mathrm{N}_{2} \mathrm{O} \text { emission } \\
\text { Yield }\end{array}$ & $0,20,40 \mathrm{t} / \mathrm{ha}$ & $\begin{array}{l}\text { - Significantly increased } \mathrm{CH}_{4} \text { emission and } \\
\text { decreased } \mathrm{N}_{2} \mathrm{O} \text { emission from paddy fields } \\
\text { under flooding irrigation vis-à-vis } \\
\text { controlled irrigation } \\
\text { - } 16.7 \text { to } 24.3 \% \text { increased yield with } \mathrm{BC}\end{array}$ \\
\hline [55] & Rice straw & $\begin{array}{l}\mathrm{pH}=10.1 \\
\mathrm{TC}=42.6 \% \\
\mathrm{TN}=0.75 \%\end{array}$ & $\begin{array}{l}\text { Soil organic } \\
\text { carbon } \\
\mathrm{CO}_{2} \text { exchange }\end{array}$ & $0,20,40 \mathrm{t} / \mathrm{ha}$ & $\begin{array}{l}\text { - Rice yields with BC addition of } 20 \text { and } \\
40 \mathrm{t} / \text { ha increased by } 24 \% \text { and } 36 \% \\
-\mathrm{CO}_{2} \text { exchange increased by } 2.4 \% \text { and } 31 \% \\
\text { - BC addition increased SOC by } 19.1 \%\end{array}$ \\
\hline [56] & Wheat straw & $\begin{array}{c}\mathrm{pH}=9.8 \\
\mathrm{TC}=418 \mathrm{~g} / \mathrm{kg} \\
\mathrm{TN}=2.8 \mathrm{~g} / \mathrm{kg}\end{array}$ & $\mathrm{CH}_{4}$ emission & - & $\begin{array}{l}\text { - } 33.8 \text { to } 43.1 \% \text { decreased } \mathrm{CH}_{4} \text { emissions } \\
\text { due to improved soil aeration }\end{array}$ \\
\hline [51] & Rice straw & - & $\begin{array}{l}\mathrm{CO}_{2} \text { emission } \\
\text { Rice yield }\end{array}$ & $20,40 \mathrm{t} / \mathrm{ha}$ & $\begin{array}{l}\text { - Increased rice yield and water use } \\
\text { efficiency by } 9.35-36.30 \% \text { and } 15.1-42.5 \% \\
-\mathrm{CO}_{2} \text { emissions from paddy fields under } \\
\text { water-saving irrigation decreased by } 2.22 \% \\
\text { compared with flood irrigation }\end{array}$ \\
\hline [14] & $\begin{array}{l}\text { Straw biochar }+ \\
\text { wood vinegar }\end{array}$ & $\begin{array}{c}\mathrm{pH}=9.8 \\
\mathrm{TN}=8.11 \mathrm{~g} / \mathrm{kg}\end{array}$ & $\begin{array}{c}\stackrel{\mathrm{NH}_{3}}{\text { volatilization }} \\
\text { vation }\end{array}$ & $7 \mathrm{t} / \mathrm{ha}$ & $\begin{array}{l}\text { - } 40.5 \mathrm{~kg} \mathrm{~N} / \mathrm{ha} \mathrm{NH} \mathrm{NH}_{3} \text { volatilization loss } \\
\text { compared with } 45.7 \mathrm{~kg} \mathrm{~N} / \text { ha from control }\end{array}$ \\
\hline [53] & Wheat straw & $\begin{array}{l}\mathrm{pH}=8.81-9.51 \\
\mathrm{TN}= \\
13.3-14.15 \mathrm{~g} / \mathrm{kg}\end{array}$ & 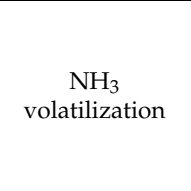 & 0.5 and $3 \mathrm{wt} \%$ & $\begin{array}{l}\text { - Higher } \mathrm{NH}_{3} \text { volatilization (20.5-31.9 } \mathrm{kg} \\
\mathrm{N} / \text { ha) after } \mathrm{N} \text { fertilization compared with } \\
\text { the control }(18.6 \mathrm{~kg} \mathrm{~N} / \mathrm{ha}) \\
\text { - The increased } \mathrm{NH}_{3} \text { volatilization at } 3 \mathrm{wt} \% \\
\mathrm{BC} \text { treatments is attributed to increased } \mathrm{pH} \\
\text { of surface floodwater and soil }\end{array}$ \\
\hline [57] & Rice straw & $\begin{array}{l}\mathrm{TC}=53.7 \mathrm{wt} \% \\
\mathrm{TN}=1.2 \mathrm{wt} \%\end{array}$ & N leaching & $\begin{array}{l}0.95 \text { t slow-released } \\
\text { fertilizer }^{\mathrm{a}}\end{array}$ & $\begin{array}{l}\text { - Decreased N leaching and more N supply } \\
\text { to the rice plant in later stages of the } \\
\text { production cycle }\end{array}$ \\
\hline [58] & $\begin{array}{l}\text { Rice straw (RS) } \\
\text { and rice husk } \\
(\mathrm{RH})\end{array}$ & $\begin{array}{c}\mathrm{pH}=7.6(\mathrm{RH}) \\
9.4(\mathrm{RS}) \\
\mathrm{TC}=47.5(\mathrm{RH}) \\
43.7(\mathrm{RS})\end{array}$ & $\mathrm{CH}_{4}$ emission & - & $\begin{array}{l}\text { - } \mathrm{BC} \text { addition decreased } \mathrm{CH}_{4} \text { emissions } \\
\text { from manure incorporated soils by } 28 \% \\
\text { to } 680 \%\end{array}$ \\
\hline [59] & Wheat straw & $\begin{array}{c}\mathrm{TC}=453.4 \mathrm{~g} / \mathrm{kg} \\
\mathrm{TN}=5.5 \mathrm{~g} / \mathrm{kg} \\
\mathrm{pH}=9.2\end{array}$ & $\begin{array}{c}\mathrm{NH}_{3} \\
\text { volatilization } \\
\text { Yield } \\
\text { N use efficiency }\end{array}$ & - & $\begin{array}{l}\text { - Fresh } \mathrm{BC} \text { reapplication increased } \mathrm{NH}_{3} \\
\text { volatilization losses } \\
\text { - Aged } \mathrm{BC} \text { (applied } 3 \text { years ago) decreased } \\
\mathrm{NH}_{3} \text { volatilization } \\
\text { - No significant difference between yields } \\
\text { - Nitrogen use efficiency was improved }\end{array}$ \\
\hline
\end{tabular}


Table 1. Cont.

\begin{tabular}{|c|c|c|c|c|c|}
\hline Reference & BC Substrate & BC Properties & Parameter & Application Rate & Effect \\
\hline$[60]$ & Rice straw & $\begin{array}{c}\mathrm{TC}=670.7 \mathrm{~g} / \mathrm{kg} \\
\mathrm{TN}=8.1 \mathrm{~g} / \mathrm{kg} \\
\mathrm{pH}=9.1\end{array}$ & $\begin{array}{l}\mathrm{CH}_{4} \text { emission } \\
\mathrm{CO}_{2} \text { emission } \\
\quad \text { Soil C }\end{array}$ & $\begin{array}{c}0,1.78,14.8 \\
29.6 \text { t/ha }\end{array}$ & $\begin{array}{l}\text { - Only } 14.8 \mathrm{t} / \mathrm{ha} \mathrm{BC} \text { decreased } \\
\mathrm{CO}_{2} \text { emissions } \\
\text { - } \mathrm{BC} \text { amendments significantly decreased } \\
\mathrm{CH}_{4} \text { emissions } \\
\text { - Soil C increased by } 5.75 \mathrm{mg} / \mathrm{g} \text { and } \\
11.69 \mathrm{mg} / \mathrm{g} \text { with } 14.8 \text { and } 29.6 \mathrm{t} / \mathrm{ha} \mathrm{BC}\end{array}$ \\
\hline [61] & Wheat straw & $\begin{array}{c}\mathrm{TC}=467 \mathrm{~g} / \mathrm{kg} \\
\mathrm{TN}=5.9 \mathrm{~g} / \mathrm{kg} \\
\mathrm{pH}=10.42\end{array}$ & $\begin{array}{l}\text { Soil properties, } \\
\text { microbial } \\
\text { biomass, and } \\
\text { enzyme activity }\end{array}$ & 20 and $40 \mathrm{t} / \mathrm{ha}$ & $\begin{array}{l}\text { - BC changed soil properties in a rice paddy } \\
\text { four years after incorporation } \\
\text { - BC induced a lower microbial metabolic } \\
\text { quotient and enzyme activity. } \\
\text { - BC altered both bacterial and fungal } \\
\text { community structures. } \\
\text { - Fungal rather than bacterial community } \\
\text { composition was more affected by BC }\end{array}$ \\
\hline$[62]$ & Rice straw & $\begin{array}{c}\mathrm{TC}=20 \% \\
\mathrm{TN}=0.26 \% \\
\mathrm{pH}=8.1\end{array}$ & $\begin{array}{l}\mathrm{CH}_{4} \text { emission } \\
\mathrm{CO}_{2} \text { emission }\end{array}$ & $4.15 \mathrm{t} / \mathrm{ha}$ & $\begin{array}{l}\text { - The lowest } \mathrm{CH}_{4} \text { emissions under } \mathrm{BC} \\
\text { treatment }\left(4.8-59 \mathrm{mg} \mathrm{C} / \mathrm{m}^{2} / \mathrm{hr}\right) \\
\text { - The lowest } \mathrm{N}_{2} \mathrm{O} \text { emissions under } \mathrm{BC} \\
\text { treatment }\left(0.15-0.26 \mu \mathrm{g} \mathrm{N} / \mathrm{m}^{2} / \mathrm{hr}\right)\end{array}$ \\
\hline [63] & Rice straw & $\begin{array}{c}\mathrm{TC}= \\
44.1-47.1 \% \\
\mathrm{TN}= \\
0.78-1.14 \% \\
\mathrm{pH}=8.9-10.43\end{array}$ & $\begin{array}{l}\mathrm{CH}_{4} \text { emission } \\
\text { Soil redox } \\
\text { potential }\end{array}$ & $1 \mathrm{~g} / 100 \mathrm{~g}$ soil & $\begin{array}{l}\text { - Low temperature } \mathrm{BC} \text { decreased soil redox } \\
\text { potential } \\
\text { - The abundance of methanogenic archaea } \\
\text { increased under low temperature } \mathrm{BC} \\
\text { - High temperature } \mathrm{BC} \text { had little effect on } \\
\mathrm{CH}_{4} \text { emissions }\end{array}$ \\
\hline$[64]$ & Rice husk & $\begin{array}{c}\mathrm{TC}=427 \mathrm{~g} / \mathrm{kg} \\
\mathrm{TN}=4.01 \mathrm{~g} / \mathrm{kg} \\
\mathrm{pH}=8.4\end{array}$ & $\begin{array}{l}\mathrm{CH}_{4} \text { emission } \\
\text { Soil redox } \\
\text { potential } \\
\text { Soil pH } \\
\text { Rice yield and } \\
\text { biomass }\end{array}$ & $\begin{array}{c}0,0.4,2,4,20 \\
\quad 40 \mathrm{~g} / \mathrm{pot}\end{array}$ & $\begin{array}{l}\text { - Significant increase in rice yield under a } \\
\text { BC rate of } 40 \mathrm{~g} / \text { pot } \\
\text { - Rates of } 20 \text { and } 40 \text { absorbed greater } \\
\text { amounts of silicon } \\
\text { - Not significantly increased } \mathrm{CH}_{4} \text { emission } \\
\text { - Soil carbon increased in proportion to the } \\
\text { BC application rate }\end{array}$ \\
\hline
\end{tabular}

a $25 \%$ BC, $4 \%$ bentonite, and $10 \%$ humid.

A number of authors have confirmed enhanced fertiliser-use efficiency after biochar application into soils $[15,65,66]$. In fact, biochar can retain nutrients in soils and promote nutrient uptake by plants which can, consequently, improve crop yields and decrease the use of fertilizing agents [35,67], as well as decreasing emission of $\mathrm{N}_{2} \mathrm{O}$ from soils [65]. The effect of biochar application on nitrogen use efficiency can even continue for some years after its application due to its impact on mitigating ammonia volatilization [59].

Findings of the effects of biochar application on crop productivity vary widely in the literature, based on soil quality amongst other factors. Significant yield improvements were reported in some studies when biochar was applied to soils of low fertility $[50,68]$, whereas soils of higher fertility showed no significant increase in biomass production and crop yields $[69,70]$.

\subsection{Biochar Production Technologies}

Carbonisation technologies including slow pyrolysis, fast pyrolysis, and gasification can be used to produce biochar. This sub-section focuses on biochar produced through thermal pyrolysis (specifically slow pyrolysis). The highest char yields are obtained by this heating method, up to $58 \%$ of the total feedstock [71]. Different scales of pyrolysis technologies are available in the market, ranging from improved cook-stoves to large industrial plants [72] estimated to process 2000 oven dry tonnes of feedstock per year (odt/yr), 20,000 odt $\mathrm{yr}^{-1}$ and 100,000 odt $\mathrm{yr}^{-1}$ in small, medium, and large scales, respectively [73].

Small-scale (i.e., household) pyrolysis facilities can benefit from pyrolytic cook-stoves that facilitate the biochar production process while recovering heat energy for cooking [74,75]. Incorporating such cook-stoves into the kitchen enables the household to have a wider range of fuels to choose from such as, in this case, the use of crop residues to replace firewood [76]. Efficiency of biochar cook-stoves in villages in North Vietnam were fully assessed by Joseph et al. [77]. Not only did the fuel wood consumption drop by between $30 \%$ and $60 \%$ compared with the traditional open hearth, the cooking 
time was decreased by up to $25 \%$ depending on the expertise of the cook and the number/types of meals cooked.

Top-lit updraft drum ovens and brick kilns are slow pyrolysis technologies, which allow biochar production at the village level [78]. The combusted pyrolysis gases from these facilities are directly released to the atmosphere, whereas pyrolytic cook-stoves burn pyrolysis gases and use the heat for cooking. At the district scale, more advanced pyrolysis technology is adopted to convert biomass into biochar. These large-scale biochar facilities usually permit easy capture of produced gases, which can be used to generate energy products (heat and electricity), adding value to biochar production and decreasing environmental costs through the displacement of fossil fuels [79].

The GHG emissions abatement potentials of biochar production was compared in a range of different pyrolysis technologies by Hammond, Shackley, Sohi, and Brownsort [73]. They reported that small-scale pyrolysis systems recover less energy than the large-scale ones and, therefore, are less efficient in delivering carbon abatement. According to Bailis et al. [80], GHG emission decreased by $119 \%$ when biochar was produced with container kiln technology in which pyrolysis gases were used for heat and power production than with the hot-tail brick kilns in which combusted gases are emitted to the atmosphere. Recycling of the pyrolysis gas plays an important role in the sustainability of biochar production, as the methane in the pyrolysis gas will have a substantial global warming effect if released uncombusted into the air.

\subsection{Enriched Biochar Systems}

Most biochar studies in rice-cropping systems have used high rates of rice straw biochar (5-48 t ha ${ }^{-1}$ ) [10,81], and Mohammadi, Cowie, Anh Mai, Anaya de la Rosa, Kristiansen, Brandão, and Joseph [66] concluded from review of available studies that the maximum agronomic benefits occur at a rate of $18.4 \mathrm{tha}^{-1}$. Prior studies that have noted the benefits of lower rates of biochar in combination with minerals [82]. The high application rates of biochar, however, add to the farmers' expenditures. Therefore, enriched biochar with a higher mineral content, surface functionality, exchangeable cations, and water-extractable organic compounds has been introduced [82-84]. Chia, Singh, Joseph, Graber, and Munroe [84] enriched a woody biochar with manures, minerals, and clays. Their resultant biochar was high in exchangeable cations, available phosphorus, and was characterized with high acid-neutralizing capacity. Enriched biochar with clay, minerals, and manure increased the concentration of dissolved organic carbon in the soil [85]. Joseph et al. [86] confirmed positive effects of enriched acacia wood-derived biochar, with clay, chicken litter, and minerals, on growth of wheat at a low application rate $\left(100 \mathrm{~kg} \mathrm{ha}^{-1}\right)$. Moreover, enhanced soil carbon and nitrogen storage and lessened GHG emissions from the soil have been linked to enrichment of woody biochar effluent with dairy manure [83]. Furthermore, the simulations application of biochar and livestock manure in rice fields considerably decrease methane emissions associated with decomposition of organic matter under anaerobic conditions [58].

\subsection{Biochar-Compost Systems}

Biochar can boost the composting process through better aeration, retaining nutrients and enhancing the quality of the final product [87]. Ammonia volatilization is avoided and, thereby, a $52 \%$ reduction in $\mathrm{N}$ losses is achieved with the addition of pine chip biochar in a 1:4 ratio when composting poultry litter [88]. One may safely conclude here that biochar may well be a suitable amendment for composting N-rich waste materials. Mixing bamboo-derived biochar with pig manure, sawdust, and wood chips (at $3 \%$ wet weight basis $(w / w)$ ) prior to composting resulted in $31 \%$ less $\mathrm{N}_{2} \mathrm{O}$ emission [89]. Agegnehu, Bass, Nelson, and Bird [48] investigated the effect of wood-derived biochar, compost produced from green waste, bagasse, and chicken manure, and biochar-compost on soil fertility, maize yield, and GHG emissions. They found that the biochar and biochar-compost-based soil management techniques can improve soil organic carbon, soil nutrient status, and increase the yield of maize by $29 \%$, and may help reduce soil GHG emissions in maize farming systems. 


\subsection{Climate Change Impact of Biochar Systems}

Biochar production systems and the subsequent application of biochar in agricultural soil, as also mentioned earlier on different occasions in the text, can contribute to mitigation of GHG emissions and help combat climate change via a range of mechanisms. This is mainly through stabilisation of biomass carbon and its storage in the soil for a long period of time as well as recovering the energy from co-products of pyrolysis process [90]. Decrease in fertiliser requirement, suppression of $\mathrm{CH}_{4}$ (mainly in rice fields) and $\mathrm{N}_{2} \mathrm{O}$ emissions from soil, and increase in crop yield as well as avoided emissions from biomass disposal by traditional methods also contribute to climate change mitigation in biochar systems. Table 2 presents the E-LCA studies on biochar addition in paddy rice fields. The review of E-LCA studies on biochar application in rice fields showed that the carbon footprint of rice produced in biochar-treated soil was estimated to range from -1.43 to $2.79 \mathrm{~kg} \mathrm{CO}_{2}$-eq per $\mathrm{kg}$ rice grain, indicating a significant reduction compared to the rice produced in the soil without biochar incorporation. The wide range of values is due to various assumptions and processes in the E-LCA studies, such as the type of feedstock, biochar stability in soils, the rate of biochar addition, soil GHG emissions, energy and fertiliser displacement impacts, and methodological factors.

Table 2. A summary of the environmental life cycle assessment (E-LCA) studies on biochar application in rice cropping systems (FU: functional unit, BC: biochar).

\begin{tabular}{|c|c|c|c|c|c|}
\hline Reference & FU & $\begin{array}{c}\text { Impact } \\
\text { Categories }^{\text {a }}\end{array}$ & System Boundaries & Reference System & GWP Results \\
\hline [91] & 1 ha of rice field & $\mathrm{CF}$ & $\begin{array}{l}\text { Rice operations + corn straw BC } \\
\text { production and application }(2.4 \mathrm{t} / \mathrm{ha}) \\
+ \text { bio-oil consumption }\end{array}$ & $\begin{array}{l}\text { Rice cropping } \\
\text { without BC }\end{array}$ & $\begin{array}{l}\mathrm{BC} \text { reduced CF by } \\
1508 \mathrm{~kg} \mathrm{CO} \text { CO }_{2}-\mathrm{eq} / \mathrm{ha}\end{array}$ \\
\hline [92] & $\begin{array}{l}1 \text { ha and } \mathrm{kg} \text { of } \\
\text { rice grains }\end{array}$ & $\mathrm{CF}$ & $\begin{array}{l}\text { Wheat straw BC production and } \\
\text { application }(20 \mathrm{t} / \mathrm{ha})+\text { farm } \\
\text { operations }+ \text { system expansion for } \\
\text { pyrolysis gas recycling }\end{array}$ & $\begin{array}{l}\text { Rice cropping } \\
\text { without BC }\end{array}$ & $\begin{array}{c}\mathrm{BC} \text { reduced } \mathrm{CF} \text { by } \\
20.4-41.3+\mathrm{CO}_{2}-\mathrm{eq} / \mathrm{ha}\end{array}$ \\
\hline$[66]$ & $\begin{array}{l}1 \mathrm{~kg} \text { of milled } \\
\text { rice }\end{array}$ & $\mathrm{CF}$ & $\begin{array}{l}\text { Rice straw BC production and } \\
\text { application }(18 \mathrm{t} / \mathrm{ha})+\text { farm } \\
\text { operations + system expansion for } \\
\text { pyrolysis gas recycling }\end{array}$ & $\begin{array}{l}\text { Rice cropping } \\
\text { without BC }\end{array}$ & $\begin{array}{c}\text { BC reduced CF of spring } \\
\text { and summer rice by } 49 \% \\
\text { and } 38 \%\end{array}$ \\
\hline [93] & $\begin{array}{l}1 \mathrm{t} \text { of dry rice } \\
\text { straw }\end{array}$ & GWP & $\begin{array}{l}\text { Rice straw BC and enriched BC } \\
\text { production and application (18 and } \\
0.5 \mathrm{t} / \mathrm{ha} \text { ) without gas recycling }\end{array}$ & $\begin{array}{l}\text { Open burning of } \\
\text { rice straw }\end{array}$ & $\begin{array}{l}0.27 \text { and } 0.61 \mathrm{tCO}_{2} \text {-eq } \\
\text { per } \mathrm{t} \text { straw, for straw } \mathrm{BC} \\
\text { and enriched } \mathrm{BC}\end{array}$ \\
\hline [94] & $\begin{array}{l}1 \mathrm{~kg} \text { of rice } \\
\text { grain }\end{array}$ & GWP, PM, HT & $\begin{array}{l}\text { BC-compost production (three } \\
\text { pyrolysis systems) and application } \\
(5 \mathrm{t} / \mathrm{ha})+\text { system expansion for } \\
\text { gas recycling }\end{array}$ & $\begin{array}{l}\text { Open burning of } \\
\text { rice straw and } \\
\text { rice husk }\end{array}$ & $\begin{array}{l}\text { Net GHG emissions } \\
\text { ranging from }-0.6 \text { to } \\
-1.1 \mathrm{tCO}_{2} \text {-eq/t rice husk }\end{array}$ \\
\hline [95] & 1 ha of rice field & GWP & $\begin{array}{l}\text { Rice field management }+ \text { Wheat } \\
\text { straw BC application }(10,20,40 \mathrm{t} / \mathrm{ha})\end{array}$ & $\begin{array}{l}\text { Rice cropping } \\
\text { without BC }\end{array}$ & $\begin{array}{l}\text { 10\%-20\% reduction in } \\
\text { GWP impact of BC } \\
\text { treatments }\end{array}$ \\
\hline [10] & 1 ha of rice field & GWP & $\begin{array}{l}\text { Rice field management }+ \text { Wheat } \\
\text { straw BC application }(24,48 \mathrm{t} / \mathrm{ha})\end{array}$ & $\begin{array}{l}\text { Double rice } \\
\text { cropping } \\
\text { without } \mathrm{BC}\end{array}$ & $\begin{array}{l}\text { 31-36\% decrease in GWP } \\
\text { impact of BC systems }\end{array}$ \\
\hline [96] & 1 ha of rice field & GWP & $\begin{array}{l}\text { Rice field management }+ \text { Wheat } \\
\text { straw BC application }(20 \mathrm{t} / \mathrm{ha})\end{array}$ & $\begin{array}{l}\text { Rice cropping } \\
\text { without BC }\end{array}$ & $\begin{array}{l}60 \% \text { reduction in net } \\
\text { GWP impact of } B C \\
\text { treatments }\end{array}$ \\
\hline [40] & 1 ha of rice field & GWP & $\begin{array}{l}\text { Rice field management }+ \text { Rice straw } \\
\text { BC application }(20 \mathrm{t} / \mathrm{ha})\end{array}$ & $\begin{array}{l}\text { Double rice } \\
\text { cropping } \\
\text { without } \mathrm{BC}\end{array}$ & $\begin{array}{l}\text { No significant difference } \\
\text { between control and BC }\end{array}$ \\
\hline [97] & 1 ha of rice field & GWP & $\begin{array}{l}\text { Rice field operations + Wheat straw } \\
\text { BC application }(20,40 \mathrm{t} / \mathrm{ha})\end{array}$ & $\begin{array}{l}\text { Rice system } \\
\text { without } B C\end{array}$ & $\begin{array}{l}\mathrm{BC} \text { reduced GWP by } \\
1.2-2.1 \mathrm{CO}_{2}-\mathrm{eq} / \mathrm{ha}\end{array}$ \\
\hline [98] & 1 ha of rice field & GWP & $\begin{array}{l}\text { Rice field management }+ \text { Wheat } \\
\text { straw BC application }(8,16 \mathrm{t} / \mathrm{ha})\end{array}$ & $\begin{array}{l}\text { Rice cropping } \\
\text { without } \mathrm{BC}\end{array}$ & $\begin{array}{l}65 \% \text { reduction in net } \\
\text { GWP of BC treatments }\end{array}$ \\
\hline
\end{tabular}

${ }^{a}$ CF, GWP, PM, and HT represent carbon footprint, global warming potential, particulate matter, and human toxicity, respectively.

A contribution analysis conducted in E-LCA studies shows that carbon storage in biochar $[5,99]$ is the dominant process in the climate effect of biochar systems. In other words, biochar is composed of stable C compounds, which significantly contribute to the stable soil organic carbon pool, as shown in Figure 1 [100]. Soil carbon sequestration could vary from $0.5 \%$ to $76.29 \%$ depending on the span 
of biochar addition, feedstock characteristics, pyrolytic conditions, etc. [101]. Many E-LCA studies unanimously have reached the conclusion that the application of biochar on farmlands contributes most $(>50 \%$ ) to the GHG abatements while the contribution may vary depending on the stable carbon content of the biochar produced [102]. The fossil energy, displaced by the use of pyrolysis gases as co-products, also makes a significant contribution of $20 \%$ to $30 \%$ to the abatement of the life-cycle emissions from biochar systems $[73,103]$ where biochar was applied to dryland crops and the FU was $1 \mathrm{t}$ of dry biomass. The energy displaced plays a minor role, less than $10 \%$, in the climate change impact of biochar systems where biochar is incorporated into paddy soil due to the substantial effect of biochar on the suppression of soil $\mathrm{CH}_{4}$ emissions and the selected $\mathrm{FU}$ was $1 \mathrm{~kg}$ of milled rice [66]. The suppression of $\mathrm{CH}_{4}$ emissions accounts for $40-70 \%$ reduction in the climate change impact of biochar systems where biochar was incorporated into paddy soils $[66,94]$. Thus, the results and the contribution of processes to GHG emissions abatement vary with crop and soil to which biochar is applied as well as with the FU of biochar systems.

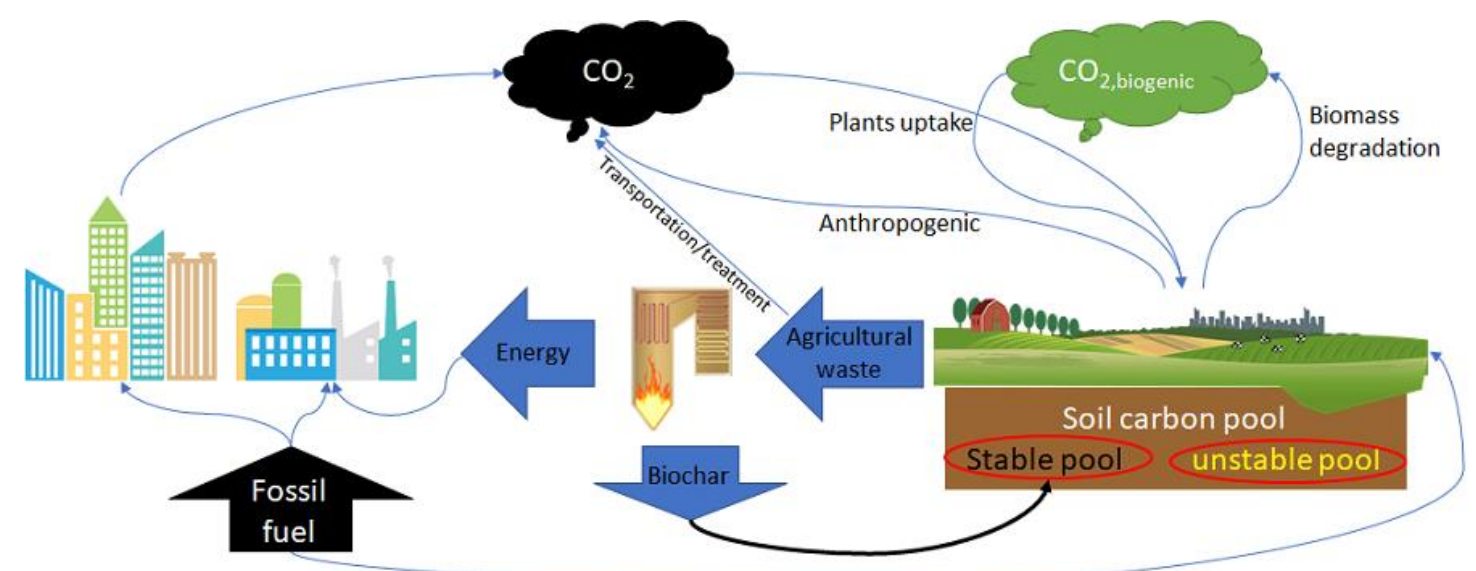

Figure 1. Contribution of biochar to the soil stable carbon pool and its role in greenhouse gas (GHG) abatement.

Life cycle assessment of biochar systems has shown that these systems reduce the emissions up to $1.2 \mathrm{t} \mathrm{CO}_{2}$-eq $\mathrm{t}^{-1}$ (dry) feedstock [90]. Recent estimations shows that the potential of biochar for sequestering atmospheric GHG emissions is about 1-1.8 Pg (petagram) $\mathrm{CO}_{2}-\mathrm{C}$ equivalent per year [104]. Some studies, in which biochar was made from purpose-grown biomass and indirect land use change was included, presented results that were outliers [18]. The broad variation in the emissions abatement can be due to methodology choices such as the choice of $\mathrm{FU}$, attributional vs. consequential LCA approach, system boundary that excludes or includes non- $\mathrm{CO}_{2}$ GHG emissions and indirect effects, or to differences in the systems studied (different biomass feedstock, different scale of pyrolysis, and biochar application rate). It should also be highlighted that, if the original materials for biochar production need any pre-treatment (such as animal manure, as shown in Reference [102]) or if considerable transportation is needed (shipping from one country to another, as shown in Reference [105]), these processes will add to the environmental load of the system and must not be neglected.

Although carbon sequestration and the avoidance of fossil-based energy have been introduced as the major pathways of GHG mitigations in biochar-based cropping systems, one should keep in mind that the reduction of $\mathrm{CH}_{4}$ and $\mathrm{N}_{2} \mathrm{O}$ emissions from paddy fields can also be looked upon as an important target [12]. The reduction of direct field emissions of $\mathrm{N}_{2} \mathrm{O}$ could only represent a minor contribution $(<5 \%)$ to the GHG abatement if only biochar application is used as the mitigation strategy [106]. On the contrary, if biochar application is used synergistically with other farm management strategies such as a modified irrigation regime and a fertiliser with a relatively-lower environmental load, the contribution to the total emission reduction can be even higher. 
Either one $\mathrm{t}$ of biomass residues or $1 \mathrm{~kg}$ of grain, mass of crop grown in biochar-amended soil, is commonly considered as FUs in E-LCA studies [66,91,107-110]. In studies in which the FU is based on crop residue management not on crop production, the total carbon footprint $(\mathrm{CF})$ (including the emissions and avoided emissions) of biochar systems was estimated to be a negative value. In these studies, the avoided emissions are usually higher than the emissions released to the air due to the carbon sequestration by biochar and also taking out the GHG emissions from the crop farming from the boundaries of the system $[18,99,108]$. The rate of biochar application, by influencing on the soil emissions, fertiliser requirement, and crop yield, is also a key parameter in such studies ranging from $0.57 \mathrm{tha}^{-1}$ [111] to $60 \mathrm{t} \mathrm{ha}^{-1}$ [36] and resulting in carbon abatement of $0.51 \mathrm{~kg} \mathrm{CO}_{2}$-eq. $\mathrm{kg}^{-1}$ corn stover and $0.30 \mathrm{CO}_{2}$-eq. $\mathrm{kg}^{-1}$ sugarcane bagasse, respectively.

The review of LCA studies indicated that using biomass for biochar production can deliver significant GHG emissions abatement relative to the conventional use of biomass. However, having an energy-efficient pyrolysis technology is important in order to achieve a net reductive effect. This implies that biochar production from simple kilns without the capture and use of pyrolytic gases must be avoided [91,112].

Pyrolysis of biomass and biochar production does not always guarantee mitigation benefit. In some studies, utilising straw and energy crops for bioenergy generation offered greater emission reduction as compared to the use of biomass for biochar soil amendment $[107,112]$. However, biochar can be negative emissions technology since it can store atmospheric carbon into the soil, leading to return back GHG concentrations to a "safe" level in the atmosphere [90]. The optimal method for biomass management should be determined after evaluating each situation and considering the reference energy system and the cumulative benefits of the biochar.

In order to test the uncertainty related to the results of the climate change impact, sensitivity analyses are often undertaken on biochar systems. In the biomass pyrolysis phase, the parameters associated with biochar yield, the fraction of recalcitrant carbon in the biochar, energy displaced, and methane emissions are evaluated [66,72]. In the agricultural phase, the parameters quantifying effects of biochar application on emissions from soil and the decrease in mineral fertiliser requirements are assessed.

The climate effect of using biochar is relatively insensitive (less than $10 \%$ variability) to the pyrolysis methane emissions, the biochar transport distance, decrease in the fertiliser requirement, and the crop yield response to biochar additions [72,73]. Meanwhile, the GHG emissions abatement due to the biochar application is moderately sensitive to the biochar yield [111], the stable carbon content of biochar [108], and suppression of soil GHG emissions particularly when biochar is applied to paddy soils [93].

LCA studies have typically investigated the climate effect of biochar systems from the perspective of the feedstock and not crop production with 'disposal of a mass of feedstock' considered as the functional unit. Calculating the carbon footprint of crop produced in biochar-treated agro-ecosystems can be useful to examine biochar's influence on different processes that contribute to climate change effects of cropping systems. E-LCA studies conducted on biochar are limited to the use of raw biochar and have not assessed applications of mineral-enriched variants. The climate impacts of compost in paddy rice systems [113] and vegetable production [114] have been investigated using the E-LCA methodology. However, life cycle assessment of applying the combination of biochar and compost to paddy soils has not been documented well.

\subsection{Human Health (Particulate Matter and Human Toxicity) Impacts}

The use of pyrolysis technology to convert crop residues into biochar may have health benefits in addition to environmental benefits. Most importantly, the use of straw for biochar may provide a solution for reducing air pollutant emissions such as particulate matter $\left(\mathrm{PM}_{10}\right)$, polycyclic aromatic hydrocarbons (PAHs), and sulphur dioxide. These are usually released on open burning of the biomass $[115,116]$. Shackley et al. [117] advised considering environmental protection and health safety 
factors when designing the biochar production technologies. For this non- $\mathrm{CO}_{2} \mathrm{GHG}$ and soot emissions that exacerbate climate change must be minimised, and emissions of dust and crystalline particles that affect human health must be curbed. Nevertheless, very few studies have considered human health effects of biochar production technologies. Sparrevik et al. [118] investigated the human toxicity and particulate matter emissions from biochar production in different pyrolysis technologies using E-LCA, applying the endpoint ReCiPe indicators. They showed that the health impacts of biochar production improved when biochar was produced in top-lit updraft stoves that allow the use of the pyrolysis gas for cooking purposes compared to the traditional earth-mound kilns without gas recovery. In an E-LCA study in Indonesia [119], the health impacts from particle emissions were greater where cocoa shells-derived biochar was applied to soil rather than used as fuel in improved briquette stoves. This is caused by using traditional wood stoves for cooking in the soil amendment scenario, emitting more particle matter emissions than the briquette stoves. In another E-LCA work in Vietnam [94], the greatest benefits in health impact was observed for the BigChar 2200 system, where biochar is made by a large-scale device and the pyrolysis gases emanating from there are captured and recovered as heat energy. The reduction of human toxicity impact of the BigChar 2200 system was mostly a result of displacing liquid petroleum gas (LPG) and fertiliser. The particulate matter and human toxicity effects of the biochar technology could also be interpreted with consideration of the pyrolysis facilities' location and the resulting emissions (e.g., indoor or outdoor). For instance, cooking is mainly conducted indoors, especially during the winter. The direct health benefits for households in the biochar cook-stove system might be more important than other systems where the facilities are located alfresco.

According to Mohammadi, Cowie, Anh Mai, Brandão, Anaya de la Rosa, Kristiansen, and Joseph [94], human toxicity impact was markedly higher when biochar was produced in the brick kiln, where pyrolysis gases are not captured, but release into the air, than when it was produced in both the cook-stove and BigChar facility. This was mostly associated with toxic emissions attributed to the upstream production processes of construction materials for the kiln. This result highlights the significance of pyrolysis gas recycling from the pyrolysis process, which confers health benefits and, thereby, influences the diffusion and adoption of the biochar technology [120]. Maximum reduction in GHG emissions, by recovering energy and sequestering soil carbon, as well as improved human health effects should be taken into account in optimizing biochar systems. Therefore, to assess the sustainability of pyrolysis biochar systems, it is necessary to consider impacts beyond GHG emissions abatement, and to address location-specific household practices. One-size will not fit all.

The application of biochar as soil amendment has also shown positive impacts on human health. Ammonia is a precursor to PM2.5. Thus, any abatement strategy to reduce ammonia emissions would have positive impacts on human health [121]. The literature review showed that the application of biochar in rice-fields significantly reduces ammonia volatilization [14,54]. Better impact on human health can be also attained by substituting fossil-based energy with renewable alternatives. However, the benefit gained by the substitution of fossil fuels can be offset if biochar substrates need some special pre-treatment operations, as shown in Reference [102]. The optimized process as well as the final use of biochar can significantly affect the benefits achieved from biochar production and application [122]. As a summary, the human health impact of biochar application is a function of the technology used to produce biochar and the final application of biochar. The modern pyrolysis plants with high standard filtration technology have significantly lower human impact induced emissions than open burning methods or household ovens. On the other hand, the use of biochar has shown positive impacts on nitrogen use efficiency in rice fields. Such positive impacts, on the one hand, can reduce synthetic nitrogen demand, and, on the other hand, can reduce ammonia volatilization from rice fields. Under both circumstances, lower ammonia volatilization would indirectly decrease impacts on human health. Therefore, the impacts of biochar application on human health must not be over-estimated or underestimated and still need further research. 


\subsection{Economic Analysis of Biochar Systems}

In the previous sub-sections, it was shown that biochar application in rice fields can create several environmental benefits, inter alia, the reduction of GHG emissions, contribution to soil carbon pool, improved plants' nutrient uptake, and increased yield. However, the biochar production and application costs are the most important concerns since a high production cost can compensate the revenue caused by higher rice yield [123]. If a production system is environmentally-friendly but not economically feasible, it will not arouse farmers' interest. Therefore, life cycle cost analysis can help to close the gap over the field application of biochar. Only a few studies have been conducted to scrutinize the production costs of biochar from different agro-wastes and the associated field application. Depending on the feedstock and the technology used, the production cost varies enormously. Harsono et al. [124] demonstrated that more than $75 \%$ of the production cost associated with biochar from palm oil empty fruit bunches rooted in diesel fuel demand needed heating up the oven at the beginning of each batch, more specifically during the first and the second hours of slow pyrolysis. It has been reportedly shown that pyrolysis plants are usually expensive to operate continuously, which can undermine the economy of biochar application in agricultural lands [125]. Of the studies that have investigated the economics of biochar as a soil amendment, a few have undertaken comprehensive cost-benefit analyses (CBA) [126,127]. The biochar application rate, the cost associated with biochar transportation to the field and field application, crop yield, and economic value of carbon sequestration can determine the overall biochar agricultural economy [128]. Bi et al. [129] demonstrated that the economy of biochar application in paddy fields highly depend on the grain yield and biochar cost. Blackwell, Krull, Butler, Herbert, and Solaiman [34] reported that woody biochar at an application rate of $1 \mathrm{tha}^{-1}$ is an economically-viable soil amendment in Australian dryland wheat farms. Their financial analysis using farm cash flow over 12 years estimates that a break-even total cost of initial biochar use can range from 40 to $190 \mathrm{AU}^{-1} \mathrm{t}^{-1}$ if the benefits decrease linearly to nil over 12 years, assuming a yield increase of $10 \%$ or a $\mathrm{P}$ fertiliser saving of $50 \%$ or both. Galinato et al. [130] have estimated the economic value of wood-derived biochar produced by slow pyrolysis technology, and used as a soil additive in wheat cultivation for its potential carbon sequestration benefits. According to their results, biochar can be a money-making technology when the biochar market price is very low $\left(12 \mathrm{US} \mathrm{t}^{-1}\right)$ or when carbon price is high ( $31 \mathrm{US} \$ \mathrm{t} \mathrm{CO}_{2}$-eq $\left.{ }^{-1}\right)$. Dickinson et al. [131] assessed biochar, for long-term improvement of farming systems in two different scenarios from economic perspectives. They confirmed that, in the first scenario, wood-derived-biochar produced through labour-based charcoal-pit production methods yielded a positive net present value (NPV) when applied to African cereal croplands. Their results from the second scenario, in which an advanced pyrolysis technology is used for forestry residues combustion and application of biochar in

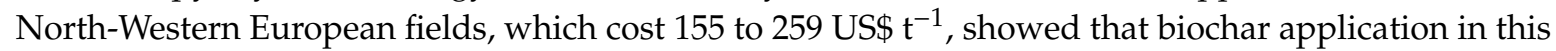
part of the world never reaches a positive NPV in economic simulations regardless of how long the investment time period is extended into the future, making it a challenge to introduce it in this area on a large scale. Regional parameters would significantly affect the overall economic benefit of biochar production and application. In rice-cultivation regions, rice straw is the most abundant feedstock for biochar production. The use of rice straw than any other feedstocks would decrease the transportation cost and increase the revenue from biochar application. On the other hand, the level of technology (e.g., household oven vs. pyrolysis plants) is also a regional parameter, which determines the economic efficiency and the quality of produced biochar.

Very little attention has been paid to the economic analysis of using biochar on small-scale farms in developing countries where the farms are characterised by low crop productivity [22,72]. Joseph, Lan Anh, Shackley, and Clare [77] conducted a cost-benefit analysis (CBA) for biochar development at the rural level in Vietnam as part of a wider technological upgrade of cooking stoves and charcoal kilns. They demonstrated that production of biochar for conditioning the soil in rice and vegetable fields over five years is an economically feasible technology (with a payback period of 1.5 years) when considered from a waste management perspective. Sparrevik, Lindhjem, Andria, 
Fet, and Cornelissen [119] undertook a study of the socioeconomic impacts of biochar production and usage in Indonesia. They noted the particular importance of evaluating the economic importance of carbon storage effects and agricultural benefits. In a study in Vietnam [132], the NPV of producing rice with alternative uses of biomass, where rice residues were used for biochar and where residues were subjected to open burning in the fields, was calculated based on their expected streams of costs and benefits. The total cost found for biochar production in the research area was estimated at $118 \mathrm{US} \$ \mathrm{t}^{-1}$ (29.5 US\$ $\mathrm{t}^{-1}$ rice residue feedstock processed). Using crop residues rather than forestry residues for biochar production is a more likely approach to reduce biochar costs to low-enough levels for smallholder farmers to gain an overall benefit from the initial capital investment committed to the biochar system. The findings of the economic analysis indicate that biochar addition can improve the NPV of rice production relative to producing rice with traditional residue management after eight years of addition [132]. The labour cost and output price have been reported as key parameters influencing the NPV of crop products in biochar-treated farming systems [22]. It should be highlighted that open burning of rice straw is still a common method for straw management in many developing countries. Open burning causes a negative ecosystem and human health impacts, as discussed earlier. Taking the monetary cost of such effects into account in the LCC can compensate for the production and application cost of biochar.

The benefits from using biochar would be enhanced if a non-trivial price for carbon abatement emerges in future pricing mechanisms [90,125]. Valuing GHG emissions abatement due to the soil application of biochar would increase the profitability of rice growing in Vietnam between 322 US\$ and 1715 US $\$ \mathrm{ha}^{-1}$, depending on the carbon price assigned to the emission reductions [132].

Using pyrolytic cook-stoves allowed small-scale (i.e., household) pyrolysis of biomass to produce biochar as well as heat energy for cooking. The improved cook-stoves could reduce indoor air pollution by displacing traditional three-stone cook-stoves. Biochar cook-stoves could also decrease time spent on fuel gathering and increase fuel efficiency by widening the variety of feedstocks that can be used. This resulted in a drop in expenses incurred on liquefied petroleum gas (LPG) and a reduction in the undue stress on forest-ecosystems [72]. Furthermore, up to $25 \%$ of cooking time could be saved in comparison with the 3S-stoves [77], and, therefore, women (who are usually the ones who cook) find more time to spend with family members and be out in the community, or on educational or other income-generating activities. However, the implementation of small-scale biochar pyrolysis might be adversely affected by high workload required for biochar production using pyrolytic cook-stoves [118].

On the other hand, more advanced pyrolysis devices at a district level need large capital outlays and local coordination (e.g., feedstock supplies and management responsibilities). The large initial capital investment and uncertainty in the longevity of the agronomic effects of biochar can result in a negative NPV of biochar use $[107,131]$. Strategies to subsidize the initial capital cost or other incentives will help protect biochar producers from the risk of negative NPV scenarios.

As rational economic agents, smallholder farmers are risk-averse due to their sensitivity to short-term losses, and this risk aversion influences the adoption of new technologies adversely [133]. Nonetheless, they are more likely to be willing to consider low-cost technologies with the potential to augment yields [134,135]. The literature review showed that the social cost has not been factored in the LCA of biochar application in croplands. It can be recommended for future research-the investigation of how household and industrial scale biochar production plants can affect farmers' economy and contribute to environmental and cost benefits of biochar application. Furthermore, the authors of this review would recommend further detailed investigations to determine the economic feasibility of different biochar production technologies as well as their suitability for small households.

\section{Conclusions}

Biochar-bioenergy production systems and subsequent land application of biochar can reduce GHG emissions by storing atmospheric carbon in the soil for a long period of time, and contributing to reduction in the use of fossil energy. A decrease in fertiliser requirement and an increase in crop yield are 
also processes by which biochar can deliver GHG mitigation. However, biochar can have inconsistent agronomic and soil effects, depending on their properties, soil types, crop species, and farmland management practices. In addition, biochar is still produced using inefficient simple kilns, which may risk high human health impacts. Appropriate technologies based on efficiently-engineered pyrolysis facilities ought to come onstream to mitigate these adverse impacts. Needless to say, these add uncertainty for estimating the climate change mitigation potential of biochar production and use. It is, therefore, imperative to analyse biochar implementation from a life-cycle perspective to uncover improvement possibilities. Furthermore, it is important to consider factors other than climate change and to determine the broader implications of adoption of biochar technologies such as human health impacts.

The review of published E-LCA studies indicates that biochar systems can deliver significant GHG emissions abatement relative to the conventional use of biomass. These E-LCA studies typically investigated the climate effect of biochar systems from the perspective of the feedstock (not the crop product) with 'disposal of a mass of feedstock' as the functional unit. Hence, there is abundant scope for further research in determining the carbon footprint of crops grown in soils amended with biochar in order to understand how biochar plays a role in mitigating climate change effects in food production systems.

The adoption of new technologies in the agricultural sector depends on the economic benefits that they can deliver. The review of published life cycle cost studies implies that the economy of biochar use in agriculture depend on the biochar application rate, the cost associated with biochar transportation to the field and field application, crop yield, and the benefit value of carbon sequestration. The climate change mitigation potential of biochar systems has been evaluated by some authors, while less attention has been paid to estimating its economic value, despite this being critical for widespread implementation.

Author Contributions: Conceptualization, A.M. Methodology, A.M. Investigation, A.M. Data curation, A.M. Writing-original draft preparation, A.M. Writing-review and editing, G.V., B.K., and S.E. Visualization, B.K. All authors have read and agreed to the published version of the manuscript.

Funding: This research received no external funding.

Conflicts of Interest: The authors declare no conflict of interest.

\section{References}

1. Sanderson, M.G.; Hemming, D.L.; Betts, R.A. Regional temperature and precipitation changes under high-end $\left(\geq 4{ }^{\circ} \mathrm{C}\right)$ global warming. Philos. Trans. R. Soc. A Math. Phys. Eng. Sci. 2011, 369, 85-98. [CrossRef] [PubMed]

2. Betts, R.A.; Collins, M.; Hemming, D.L.; Jones, C.D.; Lowe, J.A.; Sanderson, M.G. When could global warming reach $4{ }^{\circ}$ C? Philos. Trans. R. Soc. A Math. Phys. Eng. Sci. 2011, 369, 67-84. [CrossRef] [PubMed]

3. Warren, R. The role of interactions in a world implementing adaptation and mitigation solutions to climate change. Philos. Trans. R. Soc. A Math. Phys. Eng. Sci. 2011, 369, 217-241. [CrossRef] [PubMed]

4. Gómez, N.; Rosas, J.G.; Cara, J.; Martínez, O.; Alburquerque, J.A.; Sánchez, M.E. Slow pyrolysis of relevant biomasses in the Mediterranean basin. Part 1. Effect of temperature on process performance on a pilot scale. J. Clean. Prod. 2014, 120, 181-190. [CrossRef]

5. Mattila, T.; Grönroos, J.; Judl, J.; Korhonen, M.-R. Is biochar or straw-bale construction a better carbon storage from a life cycle perspective? Process. Saf. Environ. Prot. 2012, 90, 452-458. [CrossRef]

6. Lorenz, K.; Lal, R. Biochar application to soil for climate change mitigation by soil organic carbon sequestration. J. Plant Nutr. Soil Sci. 2014, 177, 651-670. [CrossRef]

7. Chandio, A.A.; Magsi, H.; Ozturk, I. Examining the effects of climate change on rice production: Case study of Pakistan. Environ. Sci. Pollut. Res. 2020, 27, 7812-7822. [CrossRef]

8. Ojo, T.; Baiyegunhi, L. Determinants of climate change adaptation strategies and its impact on the net farm income of rice farmers in south-west Nigeria. Land Use Policy 2020, 95, 103946. [CrossRef] 
9. Tokunaga, S.; Okiyama, M.; Ikegawa, M. Spatial analysis of climate change impacts on regional economies through Japan's rice production changes and innovative food industry cluster: Using the nine interregional CGE model. In Environmental Economics and Computable General Equilibrium Analysis; Springer: Tokyo, Japan, 2020; pp. 301-332.

10. Liu, J.; Shen, J.; Li, Y.; Su, Y.; Ge, T.; Jones, D.L.; Wu, J. Effects of biochar amendment on the net greenhouse gas emission and greenhouse gas intensity in a Chinese double rice cropping system. Eur. J. Soil Biol. 2014, 65, 30-39. [CrossRef]

11. Qin, X.; Li, Y.; Wang, H.; Liu, C.; Li, J.; Wan, Y.; Gao, Q.; Fan, F.; Liao, Y. Long-term effect of biochar application on yield-scaled greenhouse gas emissions in a rice paddy cropping system: A four-year case study in south China. Sci. Total. Environ. 2016, 569-570, 1390-1401. [CrossRef]

12. Sun, X.; Ding, J.; Jiang, Z.; Xu, J. Biochar improved rice yield and mitigated $\mathrm{CH}_{4}$ and $\mathrm{N}_{2} \mathrm{O}$ emissions from paddy field under controlled irrigation in the Taihu Lake Region of China. Atmos. Environ. 2019, 200, 69-77.

13. Zhang, A.; Bian, R.; Pan, G.; Cui, L.; Hussain, Q.; Li, L.; Zheng, J.; Zheng, J.; Zhang, X.; Han, X.; et al. Effects of biochar amendment on soil quality, crop yield and greenhouse gas emission in a Chinese rice paddy: A field study of 2 consecutive rice growing cycles. Field Crop. Res. 2012, 127, 153-160. [CrossRef]

14. Sun, H.; Feng, Y.; Xue, L.; Mandal, S.; Wang, H.; Shi, W.; Yang, L. Responses of ammonia volatilization from rice paddy soil to application of wood vinegar alone or combined with biochar. Chemosphere 2020, 242, 125247. [CrossRef] [PubMed]

15. Dong, D.; Feng, Q.; McGrouther, K.; Yang, M.; Wang, H.; Wu, W. Effects of biochar amendment on rice growth and nitrogen retention in a waterlogged paddy field. J. Soils Sediments 2015, 15, 153-162. [CrossRef]

16. Woolf, D.; Amonette, J.E.; Street-Perrott, F.A.; Lehmann, J.; Joseph, S. Sustainable biochar to mitigate global climate change. Nat. Commun. 2010, 1, 56. [CrossRef]

17. Lee, J.T.; Son, J.Y.; Cho, Y.S. The adverse effects of fine particle air pollution on respiratory function in the elderly. Sci. Total. Environ. 2007, 385, 28-36. [CrossRef]

18. Roberts, K.G.; Gloy, B.A.; Joseph, S.; Scott, N.R.; Lehmann, J. Life cycle assessment of Biochar systems: Estimating the energetic, economic and climate change potential. Environ. Sci. Technol. 2010, 44, 827-833. [CrossRef]

19. ISO. International Organization for Standardization, ISO 14040:2006. Environmental Management. In Environmental Management_Life Cycle Assessment_Principles and Framework; International Organization for Standardization: Geneva, Switzerland, 2006.

20. Matuštík, J.; Hnátková, T.; Kočí, V. Life cycle assessment of biochar-to-soil systems: A review. J. Clean. Prod. 2020, 259, 120998. [CrossRef]

21. Mohammadi, A.; Venkatesh, G.; Sandberg, M.; Eskandari, S.; Granström, K. Life cycle assessment of combination of anaerobic digestion and pyrolysis: Focusing on different options for biogas use. Adv. Geosci. 2019, 49, 57-66. [CrossRef]

22. Mekuria, W.; Getnet, K.; Noble, A.; Hoanh, C.T.; McCartney, M.; Langan, S. Economic valuation of organic and clay-based soil amendments in small-scale agriculture in Lao PDR. Field Crop. Res. 2013, 149, 379-389. [CrossRef]

23. Uaeieni, R.N.; Arndt, C.; Masters, W.A. Determinants of Agricultural Technology Adoption in Mozambique; Discussion Paper No. 67E; National Directorate of Studies and Policy Analysis, Ministry of Planning and Development: Maputo, Mozambique, 2011.

24. Myhre, G.; Shindell, D.; Bréon, M.F.; Collins, W.; Fuglestvedt, J.; Huang, J.; Koch, D.; Lamarque, F.J.; Lee, D.; Mendoza, B.; et al. Anthropogenic and Natural Radiative Forcing. In Climate Change 2013: The Physical Science Basis. Contribution of Working Group I to the Fifth Assessment Report of the Intergovernmental Panel on Climate Change; Stocker, T.F., Qin, D., Plattner, G.-K., Tignor, M., Allen, S.K., Boschung, J., Nauels, A., Xia, Y., Bex, V., Midgley, P.M., Eds.; Cambridge University Press: Cambridge, UK; New York, NY, USA, 2013.

25. Venkatesh, G. Life-Cycle Costing-A Primer; Bookboon: Copenhagen, Denmark, 2019; ISBN 978-87-403-2759-5.

26. Luerssen, C.; Gandhi, O.; Reindl, T.; Sekhar, C.; Cheong, D. Life cycle cost analysis (LCCA) of PV-powered cooling systems with thermal energy and battery storage for off-grid applications. Appl. Energy 2020, 273, 115145. [CrossRef]

27. Yousefi, M.; Mohammadi, A. Economical analysis and energy use efficiency in alfalfa production systems in Iran. Sci. Res. Essays 2011, 6, 2332-2336. 
28. Saber, Z.; Esmaeili, M.; Pirdashti, H.; Motevali, A.; Nabavi-Pelesaraei, A. Exergoenvironmental-Life cycle cost analysis for conventional, low external input and organic systems of rice paddy production. J. Clean. Prod. 2020, 263, 121529. [CrossRef]

29. Lehmann, J.; Abiven, S.; Kleber, M.; Pan, G.; Singh, B.P.; Sohi, S.P.; Zimmerman, A.R. Persistence of biochar in soil. In Biochar for Environmental Management: Science, Technology, and Implementation; Lehmann, J., Joseph, S., Eds.; Routledge: Milton Park, UK, 2015; pp. 233-280.

30. Singh, B.P.; Cowie, A.L.; Smernik, R.J. Biochar carbon stability in a clayey soil as a function of feedstock and pyrolysis temperature. Environ. Sci. Technol. 2012, 46, 11770-11778. [CrossRef]

31. Cheng, C.-H.; Lehmann, J.; Thies, J.E.; Burton, S.D. Stability of black carbon in soils across a climatic gradient. J. Geophys. Res. Biogeosci. 2008, 113, 1-10. [CrossRef]

32. Crane-Droesch, A.; Abiven, S.; Jeffery, S.; Torn, M.S. Heterogeneous global crop yield response to biochar: A meta-regression analysis. Environ. Res. Lett. 2013, 8, 044049. [CrossRef]

33. Cayuela, M.L.; van Zwieten, L.; Singh, B.P.; Jeffery, S.; Roig, A.; Sánchez-Monedero, M.A. Biochar's role in mitigating soil nitrous oxide emissions: A review and meta-analysis. Agric. Ecosyst. Environ. 2014, 191, 5-16. [CrossRef]

34. Blackwell, P.; Krull, E.; Butler, G.; Herbert, A.; Solaiman, Z. Effect of banded biochar on dryland wheat production and fertiliser use in south-western Australia: An agronomic and economic perspective. Aust. J. Soil Res. 2010, 48, 531-545. [CrossRef]

35. Eskandari, S.; Mohammadi, A.; Sandberg, M.; Eckstein, R.L.; Hedberg, K.; Granström, K. HydrocharAmended Substrates for Production of Containerized Pine Tree Seedlings under Different Fertilization Regimes. Agronomy 2019, 9, 350. [CrossRef]

36. Kameyama, K.; Shinogi, Y.; Miyamoto, T.; Agarie, K. Estimation of net carbon sequestration potential with farmland application of bagasse charcoal: Life cycle inventory analysis through a pilot sugarcane bagasse carbonisation plant. Aust. J. Soil Res. 2010, 48, 586-592. [CrossRef]

37. Ippolito, J.A.; Laird, D.A.; Busscher, W.J. Environmental benefits of biochar. J. Environ. Qual. 2012, 41, 967-972. [CrossRef] [PubMed]

38. Khan, S.; Chao, C.; Waqas, M.; Arp, H.P.; Zhu, Y.G. Sewage sludge biochar influence upon rice (Oryza sativa L.) yield, metal bioaccumulation and greenhouse gas emissions from acidic paddy soil. Environ. Sci. Technol. 2013, 47, 8624-8632. [CrossRef] [PubMed]

39. Liu, Y.; Lu, H.; Yang, S.; Wang, Y. Impacts of biochar addition on rice yield and soil properties in a cold waterlogged paddy for two crop seasons. Field Crop. Res. 2016, 191, 161-167. [CrossRef]

40. Shen, J.; Tang, H.; Liu, J.; Wang, C.; Li, Y.; Ge, T.; Jones, D.L.; Wu, J. Contrasting effects of straw and straw-derived biochar amendments on greenhouse gas emissions within double rice cropping systems. Agric. Ecosyst. Environ. 2014, 188, 264-274. [CrossRef]

41. Feng, Y.; Xu, Y.; Yu, Y.; Xie, Z.; Lin, X. Mechanisms of biochar decreasing methane emission from Chinese paddy soils. Soil Biol. Biochem. 2012, 46, 80-88. [CrossRef]

42. Singla, A.; Inubushi, K. Effect of biochar on $\mathrm{CH}_{4}$ and $\mathrm{N}_{2} \mathrm{O}$ emission from soils vegetated with paddy. Paddy Water Environ. 2014, 12, 239-243. [CrossRef]

43. Knoblauch, C.; Maarifat, A.-A.; Pfeiffer, E.-M.; Haefele, S.M. Degradability of black carbon and its impact on trace gas fluxes and carbon turnover in paddy soils. Soil Biol. Biochem. 2011, 43, 1768-1778. [CrossRef]

44. Zhang, A.; Cui, L.; Pan, G.; Li, L.; Hussain, Q.; Zhang, X.; Zheng, J.; Crowley, D. Effect of biochar amendment on yield and methane and nitrous oxide emissions from a rice paddy from Tai Lake plain, China. Agric. Ecosyst. Environ. 2010, 139, 469-475. [CrossRef]

45. Yanai, Y.; Toyota, K.; Okazaki, M. Effects of charcoal addition on $\mathrm{N}_{2} \mathrm{O}$ emissions from soil resulting from rewetting air-dried soil in short-term laboratory experiments. Soil Sci. Plant Nutr. 2007, 53, 181-188. [CrossRef]

46. Spokas, K.A.; Reicosky, D.C. Impacts of sixteen different biochar on soil greenhouse gas production. Ann. Environ. Sci. 2009, 3, 179-193.

47. Andreev, N.; Ronteltap, M.; Lens, P.N.L.; Boincean, B.; Bulat, L.; Zubcov, E. Lacto-fermented mix of faeces and bio-waste supplemented by biochar improves the growth and yield of corn (Zea mays L.). Agric. Ecosyst. Environ. 2016, 232, 263-272. [CrossRef]

48. Agegnehu, G.; Bass, A.M.; Nelson, P.N.; Bird, M.I. Benefits of biochar, compost and biochar-compost for soil quality, maize yield and greenhouse gas emissions in a tropical agricultural soil. Sci. Total. Environ. 2016, 543, 295-306. [CrossRef] [PubMed] 
49. Uzoma, K.C.; Inoue, M.; Andry, H.; Zahoor, A.; Nishihara, E. Influence of biochar application on sandy soil hydraulic properties and nutrient retention. J. Food Agric. Environ. 2011, 9, 1137-1143.

50. Biederman, L.A.; Harpole, W.S. Biochar and its effects on plant productivity and nutrient cycling: A meta-analysis. GCB Bioenergy 2013, 5, 202-214. [CrossRef]

51. Yang, S.; Jiang, Z.; Sun, X.; Ding, J.; Xu, J. Effects of biochar amendment on $\mathrm{CO}_{2}$ emissions from paddy fields under water-saving irrigation. Int. J. Environ. Res. Public Health 2018, 15, 2580. [CrossRef] [PubMed]

52. Sun, H.; Zhang, H.; Min, J.; Feng, Y.; Shi, W. Controlled-release fertilizer, floating duckweed, and biochar affect ammonia volatilization and nitrous oxide emission from rice paddy fields irrigated with nitrogen-rich wastewater. Paddy Water Environ. 2016, 14, 105-111. [CrossRef]

53. Feng, Y.; Sun, H.; Xue, L.; Liu, Y.; Gao, Q.; Lu, K.; Yang, L. Biochar applied at an appropriate rate can avoid increasing $\mathrm{NH}_{3}$ volatilization dramatically in rice paddy soil. Chemosphere 2017, 168, 1277-1284. [CrossRef]

54. Sun, X.; Zhong, T.; Zhang, L.; Zhang, K.; Wu, W. Reducing ammonia volatilization from paddy field with rice straw derived biochar. Sci. Total. Environ. 2019, 660,512-518. [CrossRef]

55. Yang, S.; Sun, X.; Ding, J.; Jiang, Z.; Xu, J. Effects of biochar addition on the NEE and soil organic carbon content of paddy fields under water-saving irrigation. Environ. Sci. Pollut. Res. 2019, 26, 8303-8311. [CrossRef]

56. Chen, D.; Wang, C.; Shen, J.; Li, Y.; Wu, J. Response of $\mathrm{CH}_{4}$ emissions to straw and biochar applications in double-rice cropping systems: Insights from observations and modeling. Environ. Pollut. 2018, 235, 95-103. [CrossRef]

57. Dong, D.; Wang, C.; Van Zwieten, L.; Wang, H.; Jiang, P.; Zhou, M.; Wu, W. An effective biochar-based slow-release fertilizer for reducing nitrogen loss in paddy fields. J. Soils Sediments 2019, 1-14. [CrossRef]

58. Nguyen, B.T.; Trinh, N.N.; Bach, Q.-V. Methane emissions and associated microbial activities from paddy salt-affected soil as influenced by biochar and cow manure addition. Appl. Soil Ecol. 2020, 152, 103531. [CrossRef]

59. Dong, Y.; Wu, Z.; Zhang, X.; Feng, L.; Xiong, Z. Dynamic responses of ammonia volatilization to different rates of fresh and field-aged biochar in a rice-wheat rotation system. Field Crop. Res. 2019, 241, 107568. [CrossRef]

60. Sui, Y.; Gao, J.; Liu, C.; Zhang, W.; Lan, Y.; Li, S.; Meng, J.; Xu, Z.; Tang, L. Interactive effects of straw-derived biochar and $\mathrm{N}$ fertilization on soil $\mathrm{C}$ storage and rice productivity in rice paddies of Northeast China. Sci. Total. Environ. 2016, 544, 203-210. [CrossRef] [PubMed]

61. Zheng, J.; Chen, J.; Pan, G.; Liu, X.; Zhang, X.; Li, L.; Bian, R.; Cheng, K.; Jinwei, Z. Biochar decreased microbial metabolic quotient and shifted community composition four years after a single incorporation in a slightly acid rice paddy from southwest China. Sci. Total. Environ. 2016, 571, 206-217. [CrossRef]

62. Trinh, M.V.; Tesfai, M.; Borrell, A.; Nagothu, U.S.; Bui, T.P.L.; Quynh, V.D.; Thanh, L.Q. Effect of organic, inorganic and slow-release urea fertilisers on $\mathrm{CH}_{4}$ and $\mathrm{N}_{2} \mathrm{O}$ emissions from rice paddy fields. Paddy Water Environ. 2017, 15, 317-330. [CrossRef]

63. Cai, F.; Feng, Z.; Zhu, L. Effects of biochar on $\mathrm{CH}_{4}$ emission with straw application on paddy soil. J. Soils Sediments 2017, 18, 599-609. [CrossRef]

64. Koyama, S.; Katagiri, T.; Minamikawa, K.; Kato, M.; Hayashi, H. Effects of rice husk charcoal application on rice yield, methane emission, and soil carbon sequestration in andosol paddy soil. Jpn. Agric. Res. Q. JARQ 2016, 50, 319-327. [CrossRef]

65. Liu, X.; Qu, J.; Li, L.; Zhang, A.; Jufeng, Z.; Zheng, J.; Pan, G. Can biochar amendment be an ecological engineering technology to depress $\mathrm{N}_{2} \mathrm{O}$ emission in rice paddies?-A cross site field experiment from South China. Ecol. Eng. 2012, 42, 168-173. [CrossRef]

66. Mohammadi, A.; Cowie, A.; Anh Mai, T.L.; Anaya de la Rosa, R.; Kristiansen, P.; Brandão, M.; Joseph, S. Biochar use for climate-change mitigation in rice cropping systems. J. Clean. Prod. 2016, 116, 61-70. [CrossRef]

67. Zheng, H.; Wang, Z.; Deng, X.; Herbert, S.; Xing, B. Impacts of adding biochar on nitrogen retention and bioavailability in agricultural soil. Geoderma 2013, 206, 32-39. [CrossRef]

68. Laird, D.A.; Novak, J.M.; Collins, H.P.; Ippolito, J.A.; Karlen, D.L.; Lentz, R.D.; Sistani, K.R.; Spokas, K.; Van Pelt, R.S. Multi-year and multi-location soil quality and crop biomass yield responses to hardwood fast pyrolysis biochar. Geoderma 2017, 289, 46-53. [CrossRef]

69. Tammeorg, P.; Simojoki, A.; Mäkelä, P.; Stoddard, F.L.; Alakukku, L.; Helenius, J. Biochar application to a fertile sandy clay loam in boreal conditions: Effects on soil properties and yield formation of wheat, turnip rape and faba bean. Plant Soil 2014, 374, 89-107. [CrossRef] 
70. Pandey, A.; Mai, V.T.; Vu, D.Q.; Bui, T.P.L.; Mai, T.L.A.; Jensen, L.S.; de Neergaard, A. Organic matter and water management strategies to reduce methane and nitrous oxide emissions from rice paddies in Vietnam. Agric. Ecosyst. Environ. 2014, 196, 137-146. [CrossRef]

71. Yue, Y.; Lin, Q.; Xu, Y.; Li, G.; Zhao, X. Slow pyrolysis as a measure for rapidly treating cow manure and the biochar characteristics. J. Anal. Appl. Pyrolysis 2017, 124, 355-361. [CrossRef]

72. Scholz, S.M.; Sembres, T.; Roberts, K.; Whitman, T.; Wilson, K.; Lehmann, J. Biochar Systems for Smallholders in Developing Countries; A World Bank Study: Washington, DC, USA, 2014; pp. 71-133.

73. Hammond, J.; Shackley, S.; Sohi, S.; Brownsort, P. Prospective life cycle carbon abatement for pyrolysis biochar systems in the UK. Energy Policy 2011, 39, 2646-2655. [CrossRef]

74. Whitman, T.; Enders, A.; Lehmann, J. Pyrogenic carbon additions to soil counteract positive priming of soil carbon mineralization by plants. Soil Biol. Biochem. 2014, 73, 33-41. [CrossRef]

75. Birzer, C.; Medwell, P.; MacFarlane, G.; Read, M.; Wilkey, J.; Higgins, M.; West, T. A biochar-producing, dung-burning cookstove for humanitarian purposes. Procedia Eng. 2014, 78, 243-249. [CrossRef]

76. Torres-Rojas, D.; Lehmann, J.; Hobbs, P.; Joseph, S.; Neufeldt, H. Biomass availability, energy consumption and biochar production in rural households of Western Kenya. Biomass Bioenergy 2011, 35, 3537-3546. [CrossRef]

77. Joseph, S.; Lan Anh, M.; Shackley, S.; Clare, A. Socioeconomic feasibility, implementation and evaluation of small-scale biochar projects. In Biochar for Environmental Management: Science, Technology, and Implementation; Lehmann, J., Joseph, S., Eds.; Routledge: Milton Park, UK, 2015; pp. 359-373.

78. Sparrevik, M.; Adam, C.; Martinsen, V.; Jubaedah; Cornelissen, G. Emissions of gases and particles from charcoal/biochar production in rural areas using medium-sized traditional and improved "retort" kilns. Biomass Bioenergy 2015, 72, 65-73. [CrossRef]

79. de Miranda, R.C.; Bailis, R.; Vilela, A.d.O. Cogenerating electricity from charcoaling: A promising new advanced technology. Energy Sustain. Dev. 2013, 17, 171-176. [CrossRef]

80. Bailis, R.; Rujanavech, C.; Dwivedi, P.; de Oliveira Vilela, A.; Chang, H.; de Miranda, R.C. Innovation in charcoal production: A comparative life-cycle assessment of two kiln technologies in Brazil. Energy Sustain. Dev. 2013, 17, 189-200. [CrossRef]

81. Ly, P.; Duong Vu, Q.; Jensen, L.S.; Pandey, A.; de Neergaard, A. Effects of rice straw, biochar and mineral fertiliser on methane $\left(\mathrm{CH}_{4}\right)$ and nitrous oxide $\left(\mathrm{N}_{2} \mathrm{O}\right)$ emissions from rice (Oryza sativa L.) grown in a rain-fed lowland rice soil of Cambodia: A pot experiment. Paddy Water Environ. 2015, 13, 465-475. [CrossRef]

82. Joseph, S.; Graber, E.R.; Chia, C.; Munroe, P.; Donne, S.; Thomas, T.; Nielsen, S.; Marjo, C.; Rutlidge, H.; Pan, G.X.; et al. Shifting paradigms: Development of high-efficiency biochar fertilizers based on nanostructures and soluble components. Carbon Manag. 2013, 4, 323-343. [CrossRef]

83. Sarkhot, D.V.; Berhe, A.A.; Ghezzehei, T.A. Impact of biochar enriched with dairy manure effluent on carbon and nitrogen dynamics. J. Environ. Qual. 2012, 41, 1107-1114. [CrossRef]

84. Chia, C.H.; Singh, B.P.; Joseph, S.; Graber, E.R.; Munroe, P. Characterization of an enriched biochar. J. Anal. Appl. Pyrolysis 2014, 108, 26-34. [CrossRef]

85. Lin, Y.; Munroe, P.; Joseph, S.; Henderson, R. Migration of dissolved organic carbon in biochars and biochar-mineral complexes. Pesqui. Agropecuária Bras. 2012, 47, 677-686. [CrossRef]

86. Joseph, S.; Anawar, H.M.; Storer, P.; Blackwell, P.; Chia, C.; Lin, Y.; Munroe, P.; Donne, S.; Horvat, J.; Wang, J.; et al. Effects of Enriched Biochars Containing Magnetic Iron Nanoparticles on Mycorrhizal Colonisation, Plant Growth, Nutrient Uptake and Soil Quality Improvement. Pedosphere 2015, 25, 749-760. [CrossRef]

87. Bass, A.M.; Bird, M.I.; Kay, G.; Muirhead, B. Soil properties, greenhouse gas emissions and crop yield under compost, biochar and co-composted biochar in two tropical agronomic systems. Sci. Total. Environ. 2016, 550, 459-470. [CrossRef]

88. Steiner, C.; Das, K.C.; Melear, N.; Lakly, D. Reducing nitrogen loss during poultry litter composting using biochar. J. Environ. Qual. 2010, 39, 1236-1242. [CrossRef]

89. Wang, C.; Lu, H.; Dong, D.; Deng, H.; Strong, P.J.; Wang, H.; Wu, W. Insight into the effects of biochar on manure composting: Evidence supporting the relationship between $\mathrm{N}_{2} \mathrm{O}$ emission and denitrifying community. Environ. Sci. Technol. 2013, 47, 7341-7349. [CrossRef] [PubMed]

90. Cowie, A.; Woolf, D.; Gaunt, J.; Brandão, M.; Anaya de la Rosa, R.; Cowie, A. Biochar, carbon accounting and climate change. In Biochar for Environmental Management: Science, Technology, and Implementation; Lehmann, J., Joseph, S., Eds.; Routledge: Milton Park, UK, 2015; pp. 763-794. 
91. Liu, Q.; Liu, B.; Ambus, P.; Zhang, Y.; Hansen, V.; Lin, Z.; Shen, D.; Liu, G.; Bei, Q.; Zhu, J.; et al. Carbon footprint of rice production under biochar amendment-A case study in a Chinese rice cropping system. GCB Bioenergy 2015, 8, 148-159. [CrossRef]

92. Xu, X.; Cheng, K.; Wu, H.; Sun, J.; Yue, Q.; Pan, G. Greenhouse gas mitigation potential in crop production with biochar soil amendment-A carbon footprint assessment for cross-site field experiments from China. GCB Bioenergy 2019, 11, 592-605. [CrossRef]

93. Mohammadi, A.; Cowie, A.; Anh Mai, T.L.; Anaya de la Rosa, R.; Kristiansen, P.; Brandão, M.; Joseph, S. Quantifying the greenhouse gas reduction benefits of utilising straw biochar and enriched biochar. Energy Procedia 2016, 97, 254-261. [CrossRef]

94. Mohammadi, A.; Cowie, A.L.; Anh Mai, T.L.; Brandão, M.; Anaya de la Rosa, R.; Kristiansen, P.; Joseph, S. Climate-change and health effects of using rice husk for biochar-compost: Comparing three pyrolysis systems. J. Clean. Prod. 2017, 162, 260-272. [CrossRef]

95. Zhang, A.; Bian, R.; Hussain, Q.; Li, L.; Pan, G.; Zheng, J.; Zhang, X.; Zheng, J. Change in net global warming potential of a rice-wheat cropping system with biochar soil amendment in a rice paddy from China. Agric. Ecosyst. Environ. 2013, 173, 37-45. [CrossRef]

96. Ma, Y.; Liu, D.L.; Schwenke, G.; Yang, B. The global warming potential of straw-return can be reduced by application of straw-decomposing microbial inoculants and biochar in rice-wheat production systems. Environ. Pollut. 2019, 252, 835-845. [CrossRef]

97. Wu, Z.; Zhang, X.; Dong, Y.; Li, B.; Xiong, Z. Biochar amendment reduced greenhouse gas intensities in the rice-wheat rotation system: Six-year field observation and meta-analysis. Agric. For. Meteorol. 2019, 278, 107625. [CrossRef]

98. Zhang, A.; Cheng, G.; Hussain, Q.; Zhang, M.; Feng, H.; Dyck, M.; Sun, B.; Zhao, Y.; Chen, H.; Chen, J.; et al. Contrasting effects of straw and straw-derived biochar application on net global warming potential in the Loess Plateau of China. Field Crop. Res. 2017, 205, 45-54. [CrossRef]

99. Dutta, B.; Raghavan, V. A life cycle assessment of environmental and economic balance of biochar systems in Quebec. Int. J. Energy Environ. Eng. 2014, 5, 1-11. [CrossRef]

100. Paustian, K.; Lehmann, J.; Ogle, S.; Reay, D.; Robertson, G.P.; Smith, P. Climate-smart soils. Nature 2016, 532, 49-57. [CrossRef] [PubMed]

101. Zhang, X.; Chen, C.; Chen, X.; Tao, P.; Jin, Z.; Han, Z. Persistent effects of biochar on soil organic carbon mineralization and resistant carbon pool in upland red soil, China. Environ. Earth Sci. 2018, 77, 177. [CrossRef]

102. Rajabi Hamedani, S.; Kuppens, T.; Malina, R.; Bocci, E.; Colantoni, A.; Villarini, M. Life cycle assessment and environmental valuation of biochar production: Two case studies in Belgium. Energies 2019, 12, 2166. [CrossRef]

103. Iribarren, D.; Peters, J.F.; Dufour, J. Life cycle assessment of transportation fuels from biomass pyrolysis. Fuel 2012, 97, 812-821. [CrossRef]

104. Majumder, S.; Neogi, S.; Dutta, T.; Powel, M.A.; Banik, P. The impact of biochar on soil carbon sequestration: Meta-analytical approach to evaluating environmental and economic advantages. J. Environ. Manag. 2019, 250, 109466. [CrossRef] [PubMed]

105. Robb, S.; Dargusch, P. A financial analysis and life-cycle carbon emissions assessment of oil palm waste biochar exports from Indonesia for use in Australian broad-acre agriculture. Carbon Manag. 2018, 9, 105-114. [CrossRef]

106. Thers, H.; Djomo, S.N.; Elsgaard, L.; Knudsen, M.T. Biochar potentially mitigates greenhouse gas emissions from cultivation of oilseed rape for biodiesel. Sci. Total. Environ. 2019, 671, 180-188. [CrossRef] [PubMed]

107. Clare, A.; Shackley, S.; Joseph, S.; Hammond, J.; Pan, G.; Bloom, A. Competing uses for China's straw: The economic and carbon abatement potential of biochar. GCB Bioenergy 2015, 7, 1272-1282. [CrossRef]

108. Ibarrola, R.; Shackley, S.; Hammond, J. Pyrolysis biochar systems for recovering biodegradable materials: A life cycle carbon assessment. Waste Manag. 2012, 32, 859-868. [CrossRef]

109. Mohammadi, A.; Sandberg, M.; Venkatesh, G.; Eskandari, S.; Dalgaard, T.; Joseph, S.; Granström, K. Environmental analysis of producing biochar and energy recovery from pulp and paper mill biosludge. J. Ind. Ecol. 2019, 23, 1039-1051. [CrossRef]

110. Mohammadi, A.; Sandberg, M.; Venkatesh, G.; Eskandari, S.; Dalgaard, T.; Joseph, S.; Granström, K. Environmental performance of end-of-life handling alternatives for paper-and-pulp-mill sludge: Using digestate as a source of energy or for biochar production. Energy 2019, 182, 594-605. [CrossRef] 
111. Kauffman, N.; Hayes, D.; Brown, R. A life cycle assessment of advanced biofuel production from a hectare of corn. Fuel 2011, 90, 3306-3314. [CrossRef]

112. Peters, J.F.; Iribarren, D.; Dufour, J. Biomass pyrolysis for biochar or energy applications? A life cycle assessment. Environ. Sci. Technol. 2015, 49, 5195-5202. [CrossRef] [PubMed]

113. Bacenetti, J.; Fusi, A.; Negri, M.; Bocchi, S.; Fiala, M. Organic production systems: Sustainability assessment of rice in Italy. Agric. Ecosyst. Environ. 2016, 225, 33-44. [CrossRef]

114. Zhong, J.; Wei, Y.; Wan, H.; Wu, Y.; Zheng, J.; Han, S.; Zheng, B. Greenhouse gas emission from the total process of swine manure composting and land application of compost. Atmos. Environ. 2013, 81, 348-355. [CrossRef]

115. Sanchis, E.; Ferrer, M.; Calvet, S.; Coscollà, C.; Yusà, V.; Cambra-López, M. Gaseous and particulate emission profiles during controlled rice straw burning. Atmos. Environ. 2014, 98, 25-31. [CrossRef]

116. Schweikle, J.; Spreer, W.; Intani, K.; Shafer, D.M.; Tiyayon, P.; Saehang, S.; Santasup, C.; Sringarm, K.; Wiriya, W.; Müller, J. In-field biochar production from crop residues: An approach to reduce open field burning in northern Thailand. In Proceedings of the Tropentag Conference, Berlin, Germany, 16-18 September 2015.

117. Shackley, S.; Carter, S.; Knowles, T.; Middelink, E.; Haefele, S.; Sohi, S.; Cross, A.; Haszeldine, S. Sustainable gasification-biochar systems? A case-study of rice-husk gasification in Cambodia, Part I: Context, chemical properties, environmental and health and safety issues. Energy Policy 2012, 42, 49-58. [CrossRef]

118. Sparrevik, M.; Field, J.L.; Martinsen, V.; Breedveld, G.D.; Cornelissen, G. Life cycle assessment to evaluate the environmental impact of biochar implementation in conservation agriculture in Zambia. Environ. Sci. Technol. 2013, 47, 1206-1215. [CrossRef]

119. Sparrevik, M.; Lindhjem, H.; Andria, V.; Fet, A.M.; Cornelissen, G. Environmental and socioeconomic impacts of utilizing waste for biochar in rural areas in Indonesia-a systems perspective. Environ. Sci. Technol. 2014, 48, 4664-4671. [CrossRef]

120. Singh, B.; Macdonald, L.M.; Kookana, R.S.; van Zwieten, L.; Butler, G.; Joseph, S.; Weatherley, A.; Kaudal, B.B.; Regan, A.; Cattle, J.; et al. Opportunities and constraints for biochar technology in Australian agriculture: Looking beyond carbon sequestration. Soil Res. 2014, 52, 739-750. [CrossRef]

121. Duan, N.; Khoshnevisan, B.; Lin, C.; Liu, Z.; Liu, H. Life cycle assessment of anaerobic digestion of pig manure coupled with different digestate treatment technologies. Environ. Int. 2020, 137, 105522. [CrossRef] [PubMed]

122. Lu, H.R.; El Hanandeh, A. Life cycle perspective of bio-oil and biochar production from hardwood biomass; what is the optimum mix and what to do with it? J. Clean. Prod. 2019, 212, 173-189. [CrossRef]

123. Kuppusamy, S.; Thavamani, P.; Megharaj, M.; Venkateswarlu, K.; Naidu, R. Agronomic and remedial benefits and risks of applying biochar to soil: Current knowledge and future research directions. Environ. Int. 2016, 87, 1-12. [CrossRef] [PubMed]

124. Harsono, S.S.; Grundman, P.; Lau, L.H.; Hansen, A.; Salleh, M.A.M.; Meyer-Aurich, A.; Idris, A.; Ghazi, T.I.M. Energy balances, greenhouse gas emissions and economics of biochar production from palm oil empty fruit bunches. Resour. Conserv. Recycl. 2013, 77, 108-115. [CrossRef]

125. Pratt, K.; Moran, D. Evaluating the cost-effectiveness of global biochar mitigation potential. Biomass Bioenergy 2010, 34, 1149-1158. [CrossRef]

126. Field, J.L.; Keske, C.M.H.; Birch, G.L.; DeFoort, M.W.; Cotrufo, M.F. Distributed biochar and bioenergy coproduction: A regionally specific case study of environmental benefits and economic impacts. GCB Bioenergy 2013, 5, 177-191. [CrossRef]

127. Wrobel-Tobiszewska, A.; Boersma, M.; Sargison, J.; Adams, P.; Jarick, S. An economic analysis of biochar production using residues from Eucalypt plantations. Biomass Bioenergy 2015, 81, 177-182. [CrossRef]

128. Shackley, S.; Carter, S.; Knowles, T.; Middelink, E.; Haefele, S.; Haszeldine, S. Sustainable gasification-biochar systems? A case-study of rice-husk gasification in Cambodia, Part II: Field trial results, carbon abatement, economic assessment and conclusions. Energy Policy 2012, 41, 618-623. [CrossRef]

129. Bi, Y.; Cai, S.; Wang, Y.; Xia, Y.; Zhao, X.; Wang, S.; Xing, G. Assessing the viability of soil successive straw biochar amendment based on a five-year column trial with six different soils: Views from crop production, carbon sequestration and net ecosystem economic benefits. J. Environ. Manag. 2019, 245, 173-186. [CrossRef]

130. Galinato, S.P.; Yoder, J.K.; Granatstein, D. The economic value of biochar in crop production and carbon sequestration. Energy Policy 2011, 39, 6344-6350. [CrossRef] 
131. Dickinson, D.; Balduccio, L.; Buysse, J.; Ronsse, F.; Van Huylenbroeck, G.; Prins, W. Cost-benefit analysis of using biochar to improve cereals agriculture. GCB Bioenergy 2015, 7, 850-864. [CrossRef]

132. Mohammadi, A.; Cowie, A.L.; Cacho, O.; Kristiansen, P.; Anh Mai, T.L.; Joseph, S. Biochar addition in rice farming systems: Economic and energy benefits. Energy 2017, 140, 415-425. [CrossRef]

133. Feder, G.; Just, R.E.; Zilberman, D. Adoption of agricultural innovations in developing countries: A survey. Econ. Dev. Cult. Chang. 1985, 33, 255-298. [CrossRef]

134. Pannell, D.J.; Marshall, G.R.; Barr, N.; Curtis, A.; Vanclay, F.; Wilkinson, R. Understanding and promoting adoption of conservation practices by rural landholders. Aust. J. Exp. Agric. 2006, 46, 1407-1424. [CrossRef]

135. George, T. Why crop yields in developing countries have not kept pace with advances in agronomy. Glob. Food Secur. 2014, 3, 49-58. [CrossRef]

(C) 2020 by the authors. Licensee MDPI, Basel, Switzerland. This article is an open access article distributed under the terms and conditions of the Creative Commons Attribution (CC BY) license (http://creativecommons.org/licenses/by/4.0/). 